\title{
Impacts of hypoxia on the structure and processes in pelagic communities (zooplankton, macro-invertebrates and fish)
}

\author{
W. Ekau ${ }^{1}$, H. Auel ${ }^{2}$, H.-O. Pörtner ${ }^{3}$, and D. Gilbert ${ }^{4}$ \\ ${ }^{1}$ Fisheries Biology, Leibniz Center for Tropical Marine Ecology, Fahrenheitstr. 6, 28359 Bremen, Germany \\ ${ }^{2}$ Marine Zoology (FB 2), University of Bremen, P. O. Box 330 440, 28334 Bremen, Germany \\ ${ }^{3}$ Integrative Ecophysiology, Alfred Wegener Institute, Am Handelshafen 12, 27570 Bremerhaven, Germany \\ ${ }^{4}$ Maurice-Lamontagne Institute, Fisheries and Oceans Canada, Mont-Joli, Québec, G5H 3Z4, Canada
}

Received: 30 April 2009 - Published in Biogeosciences Discuss.: 19 May 2009

Revised: 26 April 2010 - Accepted: 6 May 2010 - Published: 21 May 2010

\begin{abstract}
Dissolved oxygen (DO) concentration in the water column is an environmental parameter that is crucial for the successful development of many pelagic organisms. Hypoxia tolerance and threshold values are species- and stagespecific and can vary enormously. While some fish species may suffer from oxygen values of less than $3 \mathrm{~mL} \mathrm{O}_{2} \mathrm{~L}^{-1}$ through impacted growth, development and behaviour, other organisms such as euphausiids may survive DO levels as low as $0.1 \mathrm{~mL} \mathrm{O}_{2} \mathrm{~L}^{-1}$. A change in the average or the range of DO may have significant impacts on the survival of certain species and hence on the species composition in the ecosystem with consequent changes in trophic pathways and productivity.

Evidence for the deleterious effects of oxygen depletion on pelagic species is scarce, particularly in terms of the effect of low oxygen on development, recruitment and patterns of migration and distribution. While planktonic organisms have to cope with variable DOs and exploit adaptive mechanisms, nektonic species may avoid areas of unfavourable DO and develop adapted migration strategies. Planktonic organisms may only be able to escape vertically, above or beneath the Oxygen Minimum Zone (OMZ). In shallow areas only the surface layer can serve as a refuge, but in deep waters many organisms have developed vertical migration strategies to use, pass through and cope with the OMZ.
\end{abstract}

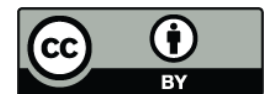

Correspondence to: W. Ekau (wekau@zmt-bremen.de)
This paper elucidates the role of DO for different taxa in the pelagic realm and the consequences of low oxygen for foodweb structure and system productivity. We describe processes in two contrasting systems, the semi-enclosed Baltic Sea and the coastal upwelling system of the Benguela Current to demonstrate the consequences of increasing hypoxia on ecosystem functioning and services.

\section{Introduction}

Oxygen is one of the key elements in metabolic processes of aquatic animals. Adaptation to environmental oxygen concentrations is crucial to survival in different habitats and in the maintenance of different life strategies. These strategies range from sluggish benthic species or organisms with long dormancy stages having low oxygen demand to highly active pelagic species such as tunas where continuous swimming requires high oxygen concentrations in the water. In many species dissolved oxygen (DO) concentrations set the limits to their horizontal and vertical distribution.

Low oxygen or hypoxia $\left(<1.4 \mathrm{~mL} \mathrm{O}_{2} \mathrm{~L}^{-1} ;<60 \mu \mathrm{mol} \mathrm{O}_{2}\right.$ $\mathrm{L}^{-1} ;<2 \mathrm{mg} \mathrm{O}_{2} \mathrm{~L}^{-1} ;<30 \%$ saturation) affects biological systems on different organisational levels. On the individual level it causes physiological changes and thus alters lifecycle performance, growth capacity and reproductive success and the vulnerability to diseases. On the species level, hypoxia constrains the vertical and horizontal distribution of species and forces individuals to depart from their normal behaviour.

Published by Copernicus Publications on behalf of the European Geosciences Union. 
Table 1. Conversion factors between different units of dissolved oxygen (DO) concentrations and pressures (IAPSO, 1985; Grashoff et al., 1983).

\begin{tabular}{lllllll}
\hline \multicolumn{5}{c}{ Dissolved oxygen (DO) concentration } \\
\hline$\mu \mathrm{Mol} \mathrm{O}_{2}$ & & mg-at $\mathrm{O}_{2}$ & & $\mathrm{mg} \mathrm{O}_{2}$ & & $\mathrm{~mL} \mathrm{O}_{2}$ \\
\hline 1000 & $=$ & 2 & $=$ & 30.88 & $=$ & 22.39 \\
500 & $=$ & 1 & $=$ & 15.44 & $=$ & 11.20 \\
32.39 & $=$ & 0.0625 & $=$ & 1 & $=$ & 0.73 \\
44.66 & $=$ & 0.0893 & $=$ & 1.379 & $=$ & 1 \\
\hline
\end{tabular}

\begin{tabular}{|c|c|c|c|c|c|c|}
\hline \multicolumn{7}{|c|}{ Oxygen partial pressure } \\
\hline $\mathrm{mm} \mathrm{Hg}$ & & $\mathrm{kPa}$ & & $\mathrm{hPa} / \mathrm{mBar}$ & & $\%$ Saturation \\
\hline 160 & $=$ & 21 & $=$ & 210 & $=$ & 100 \\
\hline 7.6 & $=$ & 1 & $=$ & 10 & $=$ & 4.76 \\
\hline 1 & $=$ & 0.133 & $=$ & 1.33 & $=$ & 0.625 \\
\hline
\end{tabular}

Hypoxia tolerance and threshold values are species- and stage-specific and can vary enormously (Miller et al., 2002). Fishes seem to be more vulnerable to low oxygen levels than crustaceans and molluscs (Vaquer-Sunyer and Duarte, 2008). While some fish larvae may suffer at oxygen values of less than $3 \mathrm{~mL} \mathrm{O}_{2} \mathrm{~L}^{-1}$ through impacted growth, development and behaviour, other organisms such as euphausiids may survive to $0.1 \mathrm{~mL} \mathrm{O}_{2} \mathrm{~L}^{-1}$ (Table 2). While sensitive species avoid even medium range oxygen levels, others such as gobies have no problem in spending hours sitting on the oxygen-free mud at the sea floor (B. Curry, personal communication, 2008)! A change in the average and the minimum and maximum DO may thus have a significant impact on the survival of certain species with consequent changes in species composition, trophic relationships, and productivity.

Hypoxic conditions occur worldwide and continue to expand in spatial extent (Stramma et al., 2008). Hypoxia is best documented in coastal areas or semi-enclosed seas (Diaz and Rosenberg, 2008). In these shallow waters where nutrient input and sedimentation is often high, organic matter accumulates on the seafloor and causes the water column to turn hypoxic or anoxic. These hypoxic conditions spread into the water column and affect pelagic communities. More extended in terms of area and volume are the oxygen minimum zones (OMZ) associated with the large upwelling systems in the eastern Pacific, the southeast Atlantic, the Arabian Sea and the Bay of Bengal (Helly and Levin, 2004). Paulmier and Ruiz-Pinob (2009) estimated the spatial extent of the OMZ $\left(\mathrm{DO}<20 \mu \mathrm{mol} \mathrm{O}_{2} \mathrm{~L}^{-1}\right)$ in the eastern Pacific to be $26.3 \times 10^{6} \mathrm{~km}^{2}$ corresponding to $\approx 17 \%$ of the whole area of the Pacific Ocean. In this case, the high production from the upwelling areas is transported far offshore and sinks to greater depth where it is degraded by microbial processes under great demand of oxygen.
While the existence of $\mathrm{OMZ}$ and their impact on plankton/pelagic organisms have been known for decades (Longhurst, 1967), the importance of OMZ in shaping behaviour and life cycles of pelagic species and the pelagic ecosystem in general has only recently come into focus. Lluch-Cota et al. (2007) in their review of the Gulf of California still mention that "...no discrete sampling of the pelagic community of the water column as related to oxygen level..." has been performed. Only recent congresses and symposia have explicitly taken up this topic.

This review paper aims at summarising and assessing the effects of hypoxic conditions on some of the dominant taxa in the pelagic environment and discussing possible consequences for the structure of pelagic ecosystems and predatorprey relationships. The physiological background for the reaction and adaptation to low oxygen is discussed; then a brief review of the response of different organism groups to changing oxygen concentrations and hypoxia is given. We focus on two ecosystems as examples for a semi-enclosed sea and an upwelling system in order to discuss the impact of hypoxia on interspecific interactions and processes on ecosystem level and try to give an outlook on the consequences that hypoxic conditions will have under changing future conditions.

Depending on the scientific discipline, oxygen is presented in various units, mainly in DO concentration or saturation. Geochemical studies mostly use $\mu \mathrm{mol}$ per litre as unit, while $\mathrm{mg}$ or $\mathrm{mL}$ per litre are widely used in physical and environmental studies. Physiological studies relate to partial pressure measured in $\mathrm{hPa}$ (mbar) or $\mathrm{kPa}$, while some are still in $\mathrm{mm} \mathrm{Hg}$. However, the oxygen demand of individuals is temperature-dependent and saturation is affected by temperature and salinity. In many cases, authors do not explicitly mention the ambient temperature and thus comparison between results is sometimes difficult. We try to harmonise the units in the review and give concentrations in $\mathrm{mL}$ $\mathrm{O}_{2} \mathrm{~L}^{-1}$ (following the paper by Levin et al., 2009) or saturation (\%) and consumption rates related to fresh weight in $\mu$ mol $\mathrm{O}_{2} \mathrm{~g}^{-1} \mathrm{~h}^{-1}$. Table 1 gives the conversion factors used and may help to transform and compare between units.

\section{Physiological background of hypoxia tolerance in marine organisms}

Ecophysiological studies aim to understand the physiological basis of zoogeographical patterns and the specific physiological characters of biota within various marine habitats. The large scale distribution patterns are determined by the temperature regime and its interactions with other abiotic factors, like water velocities, oxygen levels etc. The responsible physiological mechanisms involved are those setting the rate of energy turnover and associated oxygen demand as well as those limiting and adjusting cold and heat tolerance. These research topics have gained interest in the context of global 
Table 2. A list of oxygen consumption rates, anoxia tolerance and critical DO values for a selected number of species. Arrows in column 6 indicate the direction of impact when oxygen drops below the critical value.

\begin{tabular}{|c|c|c|c|c|c|c|}
\hline Group & Species & $\begin{array}{l}\text { Respiration rate } \\
\mu \mathrm{mol} \mathrm{O}_{2} \mathrm{~g}^{-1} \mathrm{~h}^{-1}\end{array}$ & $\begin{array}{l}\text { Anoxia tolerance } \\
\mathrm{h}\end{array}$ & $\begin{array}{l}\text { Critical values } \\
\mathrm{mLO}_{2} \mathrm{~L}^{-1} \\
\% \text { saturation }\end{array}$ & Impact & Source \\
\hline Scypho-/Hydrozoa & & $0.18-0.78$ & & & & Rutherford and Thuesen, 2005 \\
\hline Hydrozoa & Muggiaea atlantica & & & $3 \%$ & Occurrence $\downarrow$ & Rutherford and Thuesen, 2005 \\
\hline Hydrozoa & Euphysa flammea & & $<2$ & $19 \%$ & Occurrence $\downarrow$ & Rutherford and Thuesen, 2005 \\
\hline Hydrozoa & Aequorea victoria & & $>10$ & & & Rutherford and Thuesen, 2005 \\
\hline Scyphozoa & Aurelia aurita & & & 0.7 & Feeding $\uparrow$ & Shoji et al., 2005a \\
\hline Ctenophora & Mnemiopsis leidyi & & & $0.7-1$ & Occurrence $\downarrow$ & Keister et al., 2000 \\
\hline Ctenophora & & & & $1.1-1.8$ & Growth $\downarrow$ & Grove and Breitburg, 2005 \\
\hline Crustacea & Themisto gaudichaudi & 3.93 & & & Respiration $\mathrm{g}^{-1} \mathrm{DW}$ & Auel and Ekau, 2009 \\
\hline Crustacea & Copepods and euphausiids & & & $<0.1$ & Avoidance & Sameoto et al., 1987 \\
\hline Copepoda & Acartia tonsa & & & $0.04-0.08$ & Egg development $\downarrow$ & Invidia et al., 2004 \\
\hline Copepoda & Acartia tonsa & & & 0.07 & Hatching $\downarrow$ & Lutz et al., 1994 \\
\hline Crustacea & zooplankton & & & 0.2 & Abundance $\downarrow$ & Böttger-Schnack, 1996 \\
\hline Crustacea & spp. juveniles & & & $0.5-0.8$ & $\mathrm{LC}_{50}$ & Miller et al., 2002 \\
\hline Cladocera & Moina micrura & & & $0.5-0.6$ & Swimming $\uparrow$, Filtering $\downarrow$ & Svetlichny and Hubareva, 2002 \\
\hline Crustacea & spp. larvae & & & $1.1-2.6$ & $\mathrm{LC}_{50}$ & Miller et al., 2002 \\
\hline Crustacea & Oratosquilla oratoria & & & 2.78 & Survival & Kodama et al., 2006 \\
\hline Copepoda & Acartia tonsa & & 20-32 days & & Eggs & Invidia et al., 2004 \\
\hline Copepoda & Acartia bifilosa & & 10 months & & Eggs & Katajisto, 2004 \\
\hline Cephalopoda & spp. & $0.3-8.8$ & & $2-12 \%$ & pelagic spp & Seibel et al.. 1997 \\
\hline Cephalopoda & Dosidicus gigas & 1.4 & & & hypoxic condition & Rosa and Seibel, 2008 \\
\hline Cephalopoda & Dosidicus gigas & 7.0 & & & normoxic condition & Rosa and Seibel, 2008 \\
\hline Cephalopoda & Gonatus onyx & & & 0.5 & Occurrence $\downarrow$, adults & Hunt and Seibel, 2000 \\
\hline Cephalopoda & Gonatus onyx & & & 1 & Occurrence $\downarrow$, juveniles & Hunt and Seibel, 2000 \\
\hline Cephalopoda & & & & 1.4 & Occurrence $\downarrow$ & Rabalais et al., 2001 \\
\hline Cephalopoda & Lodig pealei & & & 2.1 & Catch $\downarrow$ & Howell and Simpson, 1994 \\
\hline Cephalopoda & Loligo vulgaris & & & 3 & Spawning & Roberts, 2005 \\
\hline Cephalopoda & & & & 3 & Avoidance & Roberts and Sauer, 1994 \\
\hline Cephalopoda & & & & $19 \%$ & & Hunt and Seibel, 2000 \\
\hline Cephalopoda & Lolliguncula brevis & & & $41-49 \%$ & Onset anaerobic metabol. & Zielinski et al., 2000 \\
\hline Pisces & Pogonophryne scotti & 0.91 & & & at $-1{ }^{\circ} \mathrm{C}$ & Saint-Paul et al., 1988 \\
\hline Pisces & Gadus morhua & $1.1-2.4$ & & & $5-15^{\circ} \mathrm{C}$ & Schurmann and Steffensen, 1997 \\
\hline Pisces & Ammodytes tobianus & 2.16 & & & & Behrens and Steffensen, 2007 \\
\hline Pisces & Gobius cobitis & $1.27-3.62$ & & & at $12.5-25^{\circ} \mathrm{C}$ & Berschik et al., 1987 \\
\hline Pisces & Sardinops sagax & 4.31 & & & Lowest swimming resp. & van der Lingen, 1995 \\
\hline Pisces & Sarda chiliensis & 7.81 & & & & Sepulveda et al., 2003 \\
\hline Pisces & Katsuwonus pelamis & 16.3 & & & & Gooding et al., 1981 \\
\hline Pisces & Sprattus sprattus & & & $0.5 / 7 \%$ & Distribution & Kaardvedt et al., 2009 \\
\hline Pisces & Gobiodon, Paragobiodon & & & $3 \%$ & Occurrence, at night & Nilsson et al., 2007a \\
\hline Pisces & Trachurus capensis & & & $10 \%$ & & $\begin{array}{l}\text { A. Kunzmann, personal } \\
\text { commmunication, } 2008\end{array}$ \\
\hline Pisces & spp. juveniles & & & $0.4-1.1$ & $\mathrm{LC}_{50}$ & Miller et al., 2002 \\
\hline Pisces & Fundulus grandis & & & 1 & Gonad size $\downarrow$ & Landry et al., 2007 \\
\hline Pisces & spp. larvae & & & $1-1.7$ & $\mathrm{LC}_{50}$ & Miller et al., 2002 \\
\hline Pisces & Gadus morhua & & & $21 \%$ & $\mathrm{LC}_{50}$ & Plante et al., 1998 \\
\hline Pisces & Pseudopleuronectes americanus & & & $<1.4$ & Growth $\downarrow$ & Bejda et al., 1992 \\
\hline Pisces & Cynoscion regalis & & & 1.4 & Distribution & Tyler et al., 2007 \\
\hline Pisces & Gobiosoma bosc & & & 1.4 & Distribution & Keister et al., 2000 \\
\hline Pisces & Anchoa mitchilli eggs & & & 1.4 & Distribution & MacGregor and Houde, 1996 \\
\hline Pisces & spp. & & & $1.2-1.5$ & Abundance/catch $\downarrow$ & Dethlefsen and Westernhagen, 1983 \\
\hline Pisces & spp. & & & 1.7 & Abundance $\uparrow$ & Burleson et al., 2001 \\
\hline Pisces & Menidia beryllina & & & $<2.1$ & Avoidance & Weltzien et al., 1999 \\
\hline Pisces & Clupea harengus & & & $10-25 \%$ & School disruption & Domenici et al., 2000 \\
\hline Pisces & Gobiosoma bosc & & & $<1.5$ & Larval mortality $\uparrow$ & Breitburg, 1994 \\
\hline Pisces & Anchoa spp. & & & 1.75 & Distribution & Taylor et al., 2007 \\
\hline Pisces & Gadus morhua & & & $16.5-30 \%$ & Temperature dependance & Schurmann and Steffensen, 1997 \\
\hline Pisces & Gadus morhua & & & 2 & Vertical larval distrib. $\downarrow$ & Grønkjaer and Wieland, 1997 \\
\hline Pisces & Anchoa mitchelli & & & $<2.1$ & Larval mortality $\uparrow$ & Breitburg, 1994 \\
\hline Pisces & Electrophorus electricus & & & $2.1-2.8$ & Avoidance & Crampton, 1998 \\
\hline Pisces & spp. & & & $2-2.9$ & Abundance/catch $\uparrow$ & Howell and Simpson, 1994 \\
\hline Pisces & Acipenser transmontanus & & & $50 \%$ & Activity $\downarrow$ & Crocker and Cech, 1997 \\
\hline Pisces & Sardinops sagax & & & $2.5-3$ & Vertical larval distrib. $\downarrow$ & Ekau and Verheye, 2005 \\
\hline Pisces & Engraulis capensis & & & $2.5-3$ & Vertical larval distrib. $\downarrow$ & Ekau and Verheye, 2005 \\
\hline Pisces & Clupea harengus & & & $50 \%$ & Hatching length $\downarrow$ & Braum, 1973 \\
\hline Pisces & Katsuwonus pelamis & & & $3-3.5$ & Distribution & Barkley et al., 1978 \\
\hline Pisces & Gadus morhua & & & $70 \%$ & Abundance $\uparrow$ & Chabot and Claireaux, 2008 \\
\hline Pisces & Gadus morhua & & & $70 \%$ & Growth $\downarrow$ & Chabot and Claireaux, 2008 \\
\hline
\end{tabular}


warming and associated shifts in the geographical distribution of marine ectothermic animals.

Traditional concepts in animal physiology have considered the effects of individual factors like oxygen (Grieshaber et al., 1994), temperature (Angiletta, 2009), carbon dioxide (Pörtner et al., 1998) or salinity and have addressed the specific responses in organisms from various habitats. For analyses of the complex interactions and effects of various environmental factors at the ecosystem level these traditional concepts need to be integrated in order to achieve more realistic estimates of sensitivity to environmental change. Progress in recent years has identified how such integration can be carried out and implemented (e.g. Pörtner and Farrell, 2008; Pörtner, 2010). The traditional principles addressing individual factors and their integration operate similarly across animal phyla and will accordingly be briefly summarized from a general point of view. Those principles are emphasized which provide a link between physiology and ecology and support an understanding of ecosystem level processes.

In the context of organismic requirements for ambient oxygen and of the associated levels of hypoxia sensitivity the concepts of oxyconformity, oxyregulation, and the critical partial pressure of oxygen $(\mathrm{Pc})$ have been revisited based on an integration of systemic and cellular processes in declining ambient oxygen tensions (Pörtner and Grieshaber, 1993). It has been recognized early that animals may show different patterns of oxygen consumption in response to changes in partial pressure of oxygen $\left(\mathrm{P}_{\mathrm{O}_{2}}\right)$. Some keep their oxygen consumption more or less constant in a wide range of $\mathrm{P}_{\mathrm{O}_{2}}$ and are called oxyregulators. Others reduce their oxygen uptake with decreasing oxygen tensions and have, consequently, been termed oxyconformers. Intermediate responses exist too (Mangum and van Winkle, 1973). Nonetheless, categorization is useful to identify metabolic patterns of oxyconformity and the underlying mitochondrial mechanisms in both benthic and pelagic species. In the pelagic, Rutherford and Thuesen (2005) classified some medusae as being oxyconformers. Circumstantial evidence for the presence of an alternative mitochondrial oxidase (cytochrome o) exists in lower marine invertebrates, e.g. sipunculids, annelids or bivalves (Pörtner et al., 1985; Buchner et al., 2001; Tschischka et al., 2000). This oxidase might represent an ancient mechanism of oxygen detoxification used in animals which live in hypoxic environments. Only these aerobic oxyconformers, which display oxyconformity at cellular and mitochondrial levels should be considered as "true" oxyconformers, whereas the progressive drop in oxygen consumption seen during extreme hypoxia below a critical partial pressure of oxygen $(\mathrm{Pc})$ in both oxyconformers and oxyregulators is caused by oxygen supply being insufficient to completely cover energy demand by aerobic metabolic pathways. Anaerobic metabolism sets in eventually (see below). Variable intracellular oxygen levels drive variable rates of oxygen consumption in oxyconformers, whereas this rate remains constant above the Pc in oxyregulators. However, aerobic oxyconformers can be behavioural oxyregulators, once they manage to keep oxygen levels in their water burrow or in their body fluids constant through compensatory adjustments in ventilatory (and circulatory) efforts. Irrigation of worm burrows in the sediment or ventilation of gill chambers in bivalves may in fact involve apparent oxyregulation in these animals. By keeping oxygen in their body fluids at minimal levels (e.g. Massabuau, 2001) they could minimize the extent to which oxygen detoxification by cytochrome o is necessary. Variable ventilatory capacities might thus explain the range in responses elaborated by Mangum and van Winkle (1973).

The terms oxyconformity and oxyregulation have been defined for quiescent animals, which display baseline or "standard" metabolic rate. Standard metabolic rate (SMR) is defined as the lowest rate of oxygen consumption for oxyregulators, "which would be obtained when all organs were absolutely at rest". The data available for several oxyregulators suggest that this rate is maintained down to the Pc. This clear physiological definition of SMR excludes the "perturbing" effect of spontaneous muscular activity on the pattern of oxygen consumption during hypoxia. SMR is analysed (1) by correcting for the influence of spontaneous activity during long term measurements, (2) by extrapolating to zero activity during analyses of aerobic metabolism at various activity levels, or (3) by determining metabolic rate at or slightly above the Pc, to exclude the effect of oxyconformity mechanisms. However, focusing on standard metabolic rate may not be satisfying, as animals need to perform and are active at ecosystem level such that the analysis falls short of providing complete ecosystem level implications. Nonetheless, for a principle comparison of the responses of oxyconformers and oxyregulators to progressive hypoxia the concept of standard metabolic rate is relevant. According to a simple model the different patterns of conformity and regulation and associated metabolic transition phases can be analysed and some ecosystem level implications elaborated (Fig. 1). Initially, the concept of a critical partial pressure of oxygen was introduced to characterize hypoxia sensitivity as the oxygen tension below which an oxyregulating animal is no longer able to maintain its rate of oxygen consumption independent of the ambient oxygen tension and starts to exhibit a decreasing rate of oxygen uptake. This definition is not applicable to quantify hypoxia sensitivity in all animals including oxyconformers. Recent studies, which include an analysis of anaerobic processes at different oxygen tensions, demonstrate that this $\mathrm{Pc}$ is not only characterized by the transition from an oxygen independent to an oxygen dependent pattern of oxygen consumption, but also by the onset of an anaerobic energy metabolism. Thus the failure of oxyregulation and the onset of anaerobiosis coincide in response to an insufficient capacity for oxygen uptake and transport via the blood (Pörtner and Grieshaber, 1993). This extended concept of the Pc becomes applicable in both oxyregulating and oxyconforming species. Combined analyses of changes in the 
overall rate of oxygen consumption, in oxygen transport via the body fluids, and in the transition from aerobic to anaerobic energy production are required to unequivocally establish the critical Pc.

Anaerobic ATP production processes are located in the cytosol and within mitochondria leading to the formation of either lactate (or opines which are condensation products of glycolytic pyruvate with specific amino acids like glycine, alanine, arginine or taurine in marine invertebrates; Grieshaber et al., 1994) or succinate. These metabolites may, in most cases, be suitable cytosolic and mitochondrial markers of an anaerobic metabolism. However, muscular activity may lead to pyruvate and lactate or opine accumulation when mitochondria are still performing aerobically. This emphasizes the relevance of analyzing mitochondrial processes in quantifying hypoxia sensitivity. For example, long-term incubation of oxyconforming Sipunculus nudus below the Pc demonstrated that succinate accumulation occurred before the glycolytic end products were formed (Hardewig et al., 1991). Consequently, anaerobic glycolysis became involved in resting individuals of this species only when oxygen supply fell to an extent, which no longer allowed (all of) the mitochondria to produce energy by aerobic means. This observation presents strong evidence that the animals exhibited their minimal aerobic metabolic rate at the Pc. As a consequence, the metabolic rate at the Pc can be seen to represent the standard metabolic rate (SMR) of both oxyregulating and oxyconforming organisms. Furthermore, oxyregulators are able to maintain low metabolic rate (SMR) at $\mathrm{P}_{\mathrm{O}_{2}}$-values higher than $\mathrm{Pc}\left(\mathrm{Pc}_{\mathrm{M}}\right.$ in Fig. 1), whereas the oxygen consumption of "true" oxyconformers increases above Pc. These animals show a second $\mathrm{Pc}\left(\mathrm{Pc}_{\mathrm{R}}\right.$ in Fig. 1), above which the elevated rate of oxygen uptake finally remains constant.

Further observations characterize the Pc. On systemic and cellular levels, the transition from aerobic to anaerobic energy metabolism is either linked to the pronounced decrease or even increase in oxygen consumption. The latter may occur as a result of a stimulatory response elicited by e.g. lactate accumulation (Pörtner at al., 1994; Pinz and Pörtner, 2003). This again eliminates uncertainty in quantifying hypoxia sensitivity in those oxyregulators where such stimulation upon progressive hypoxia is observed. The critical oxygen tension is also characterized by the onset of a critical reduction of oxygen transfer via the blood or other body fluids. In response to such oxygen deficiency, those animals, which are able to tolerate long-term exposure to hypoxia, reduce overall energy expenditure below the Pc and undergo metabolic depression. This represents a strategy of passive resistance to transient hypoxia, as regularly experienced by animals living in the intertidal zone.

As indicated above the Pc is a variable reflecting sensitivity of a species or life stage to fluctuations in ambient oxygen levels. The Pc increases with organisational complexity, from unicellular organisms to complex organisms like animals. Here mechanisms causing additional limitations of

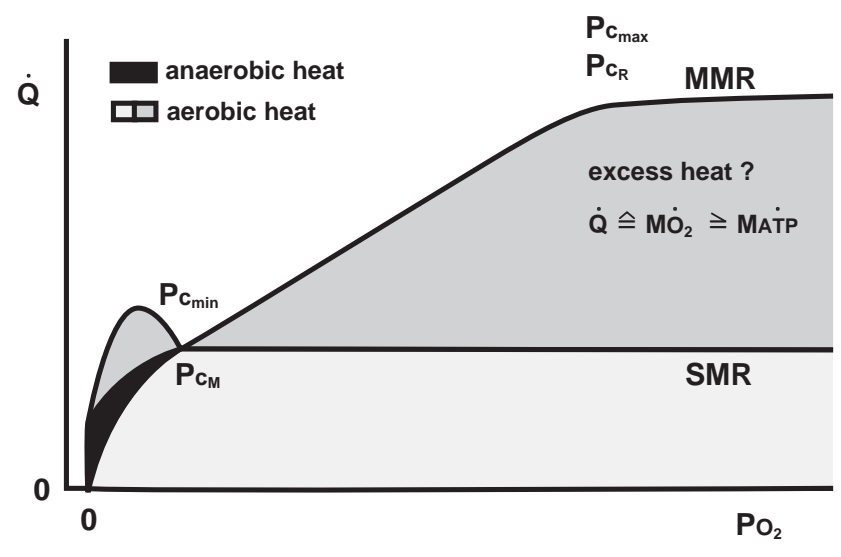

Fig. 1. Graphical presentation of a model used for the comparison of the physiological responses (given as combined ventilatory and cardiac output $-Q$ ) of oxyconforming and oxyregulating animals in declining oxygen tensions (modified after Pörtner and Grieshaber, 1993). For the sake of clarity, oxygen consumption rates and critical oxygen values are compared in absolute terms, neglecting the fact that standard metabolic rates are variable between species and individuals. $\mathrm{Pc}_{\mathrm{M}}$ is the $\mathrm{Pc}$ below which anaerobiosis starts, $\mathrm{Pc}_{\mathrm{R}}$ is the Pc of constant aerobic metabolic rate. SMR is the standard metabolic rate, the minimum metabolic rate in complete aerobiosis (at $\mathrm{Pc}_{\mathrm{M}}$ ), excluding locomotory activity. An increase in oxygen consumption may occur in oxyregulators below $\mathrm{Pc}_{\mathrm{M}}$ (see text). An aerobic oxyregulator is able to maintain $\mathrm{SMR}$ at oxygen partial pressure values above $\mathrm{Pc}_{\mathrm{M}}, \mathrm{Pc}_{\mathrm{M}}$ equals $\mathrm{Pc}_{\mathrm{R}}$. However, it is able to reach maximum metabolic rate during phases of maximum aerobic exercise. Maximum aerobic metabolic rate is reached by full exploitation of energy turnover capacity (high energy consumption and associated production). Maintaining this maximum leads to higher levels of $\mathrm{Pc}\left(\mathrm{Pc}_{\max }\right)$ and thus, enhanced hypoxia sensitivity as compared to SMR. In contrast, an aerobic oxyconformer regularly exceeds SMR once exposed to high ambient oxygen levels and passively exploits its aerobic scope above $\mathrm{Pc}_{\mathrm{M}}, \mathrm{Pc}_{\mathrm{R}}>\mathrm{Pc}_{\mathrm{M}}$.

oxygen provision become involved: (1) In a cell diffusion limitation of oxygen in the membrane and the cytoplasm together with the rate of mitochondrial respiration and, perhaps, the clustering of mitochondria in areas of high energy needs define the point at which the oxygen concentration finally becomes limiting and anaerobiosis commences. (2) At tissue level capillary $\mathrm{P}_{\mathrm{O}_{2}}$ (in animals with closed circulatory systems) or bulk venous $\mathrm{P}_{\mathrm{O}_{2}}$ (in animals with an open circulatory system) are key parameters in determining whether oxygen provision is sufficient for the individual cell. The maintenance of the pressure head for sufficient oxygen supply depends upon energy demand, the rate of perfusion, the density of the capillaries and on blood oxygen transport. (3) For the whole organism the required pressure head, i.e. the Pc, will also depend upon the structures and functions of the gas exchange organ and the circulatory system, and upon the $\mathrm{O}_{2}$ affinity of the pigment and its regulation. These mechanisms are subject to modification during evolutionary adaptation and also, to a lesser extent, to short-term 


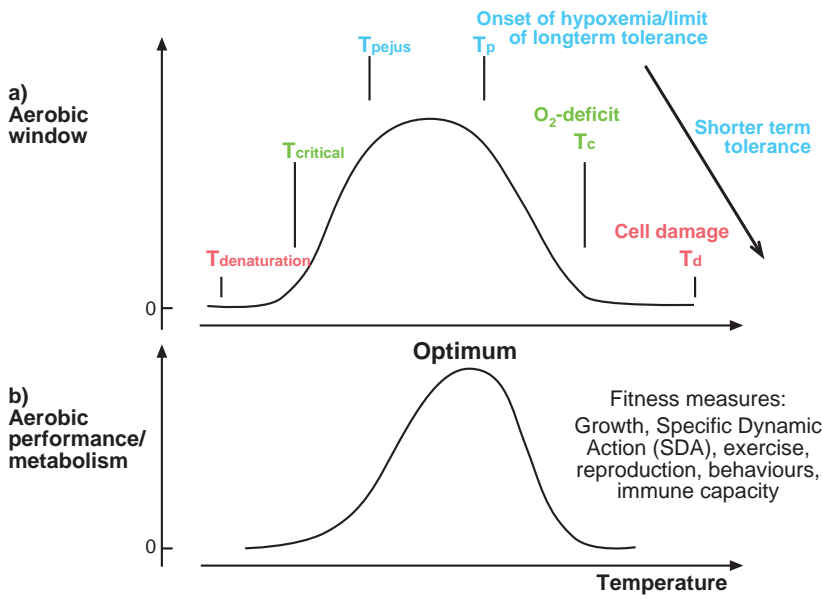

Fig. 2. Conceptual model of how ocean warming and hypoxia, as interacting stressors, shape the thermal window of performance of a species, population or life stage, based on the concept of oxygen and capacity limited thermal tolerance (after Pörtner and Knust, 2007; Pörtner et al., 2009). Optimized oxygen supply to tissues between low and high pejus temperatures $(a)$ combined with the kinetic stimulation of performance rates by warming supports temperature dependent performance and a functional optimum (i.e. an optimum of aerobic scope) close to upper pejus temperature $(b)$. This reflects fitness due to functional capacity in ecosystem level processes such as competition, foraging, immune response, growth and behaviours. Ambient hypoxia causes a narrowing of thermal windows and possibly, lower performance optima due to lower functional capacities at reduced systemic oxygen tensions. The graph depicts acute performance levels and limitations in response to short term temperature fluctuations. On longer time scales, changing temperatures elicit acclimatization as a limited shift of performance optima and limits on the temperature scale. Note that the passive tolerance range (starting beyond pejus temperatures) is a relevant component of the niche in some cases, when it is exploited for a limited time under extreme conditions, e.g. in invertebrates exposed to combined hypoxia and temperature extremes in the intertidal zone. Hypoxia tolerance is at a maximum in the thermal optimum, due to optimal oxygen supply capacity causing Pc to be minimal. Hypoxia sensitivity is enhanced at thermal extremes (Tc) when oxygen supply capacity falls in relation to oxygen demand, and the Pc rises towards its maximum, indicated by the onset of anaerobic metabolism at critical temperatures and ambient, even normoxic oxygen tensions.

acclimation to hypoxic exposure. When fully functional they alleviate the principle problem that body surface to volume ratios are low and unfavourable for oxygen diffusion at large body sizes. Finally and accordingly, hypoxia sensitivity and the Pc increase with increasing body size of an animal, leading to allometric enhancement of oxygen limitation within a species.

A summary of the different patterns discussed for regulators and conformers leads to a simple model (see Fig. 1) where, generally, oxygen consumption at the Pc is equivalent to standard metabolic rate, even when considering that a potential increase in oxygen uptake below the Pc may occur as a response linked to the onset of anaerobic metabolism. SMR or Pc varies between species and their life stages as well as between individuals of the same species according to body size. SMR and Pc may even be variable in an individual animal according to its physiological state under the prevailing endogenous and exogenous conditions. For example, long term acclimatization to hypoxia may occur (see above), such that the Pc and SMR may be lower for individuals of the same species exposed to hypoxia as compared to ones exposed to higher oxygen tensions. Once an animal displays a metabolic rate higher than SMR, the Pc of aerobic metabolism will rise and reach a high $\mathrm{Pc}_{\max }$ at maximum metabolic rate (see Fig. 1). From an integrative point of view these concepts of hypoxia sensitivity have become relevant in the context of thermal limitation and its role in understanding climate change effects on marine ecosystems (Pörtner, 2010).

Temperature and hypoxia would traditionally be considered as different environmental factors, with specific implications for whole organism functioning. Studies of temperature-dependent oxygen supply, mode of metabolism and associated mechanisms of thermal adaptation in marine invertebrates and fishes across latitudes have suggested a role of oxygen supply in thermal limitation. These studies have led to the development of the concept of oxygen and capacity limited thermal tolerance in marine water breathers. Further effort has demonstrated that these physiological principles are in fact operative at the ecosystem level (Pörtner and Knust, 2007; Pörtner and Lannig, 2009). Thermal stress causes systemic hypoxemia at both ends of the thermal window. Temperature-dependent oxygen supply capacity sets the width of thermal window of an animal (Fig. 2). Thermally induced hypoxemia and associated stress and signalling mechanisms likely shape acclimation responses at various, molecular to whole organism levels (e.g. Kassahn et al., 2009). Thermal adaptation affects SMR and the cost of maintenance as well as energy budget of an organism. Thermal adaptation likely plays an important role in setting sensitivity to hypoxia. The integration of the concepts of thermal and hypoxia sensitivity leads to new insight and perspectives relevant for hypoxia tolerance (Fig. 2, cf. Pörtner, 2010). In brief, the thermal optimum reflects improved hypoxia tolerance. Close to the upper pejus temperature the capacity of ventilatory and circulatory systems to provide oxygen to tissues is maximal and, accordingly, $\mathrm{Pc}_{\mathrm{M}}$ is minimal. The positive balance between oxygen supply capacity and oxygen demand is maintained during cooling to the lower pejus temperature. Cooling lowers the capacity for oxygen supply and also metabolic rate and provides elevated solubility and levels of ambient oxygen. Cooling therefore enhances the capacity to tolerate hypoxia, but only in organisms acclimatized or adapted to cold. Hypoxemia setting due to thermal limitation below both lower and upper Tp's causes a rise in $\mathrm{Pc}$, thus indicating progressive reduction of hypoxia tolerance at the borders of the thermal window. At both critical 
temperatures, the $\mathrm{Pc}$ is maximal and becomes equivalent to ambient oxygen tensions (e.g. Zakhartsev et al., 2003).

As a corollary, the species-specific thermal window and the temperature sensitivity of Pc reflect the temperature dependence of hypoxia sensitivity and also the integration of thermal and hypoxia sensitivities. These relationships require consideration in analyses of hypoxia resistance. Conversely, hypoxia and other stressors like carbon dioxide will affect thermal tolerance limits and also the processes involved in thermal acclimatization and adaptation, which counteract thermally induced hypoxemia and thereby also improve hypoxia tolerance. The specialization of whole organism functioning on limited temperature ranges emerges as a key element explaining current observations of climate change effects on ecosystems. As a perspective, the operation of species and their sensitivity to environmental factors including hypoxia may in fact be best understood if analysed on a matrix of temperature dependent performance (Pörtner and Knust, 2007; Pörtner and Farrell, 2008; Pörtner et al., $2008,2009)$. These generalized and largely hypothetical aspects have been extrapolated from mechanistic knowledge and require testing and specification through investigation in individual species and ecosystems.

\section{Reaction of different taxonomic groups to hypoxic conditions in the pelagic system}

\subsection{Gelatinous plankton}

Several taxonomic groups are covered by the terms gelatinous plankton or jellyfish. Scyphozoan medusae are the largest representatives and most dominant in the pelagic zone. Hydrozoan medusae and ctenophores are other important members of this group. Jellyfish feed carnivorously on other zooplankton and they are competitors for food to pelagic crustaceans and fish. Besides jellyfish, salps and appendicularia are often also considered as gelatinous plankton. In contrast to jellyfish, they are very efficient filterfeeders collecting food particles in a wide size range from bacteria to phytoplankton and mesozooplankton (size range: $<1 \mu \mathrm{m}$ to $1 \mathrm{~mm}$ ). Dominant filter feeders consume a wide variety of potential prey and channel a large fraction of available resources towards a single species, which severely reduces the total remaining resources and opportunities for trophic niche specialisation for more selective consumers. Therefore, pelagic communities dominated by filter feeders tend to be rather simple with only a few species, short food chains and a highly efficient transfer of carbon and energy throughout the food chain.

The observed increase in abundance of gelatinous zooplankton during recent years (Attrill et al., 2007; Finenko et al., 2006; Graham, 2001; Lynam et al., 2006; Pauly et al., 2009) may be a consequence of their better adaptation to disturbed environmental conditions such as eutrophication, habitat modification or reduced oxygen (Richardson et al., 2009).

Respiration rates of gelatinous zooplankton seem to be rather low. Rutherford and Thuesen (2005) found respiration rates of 0.18 to $0.78 \mu \mathrm{mol} \mathrm{O}_{2} \mathrm{~g}^{-1} \mathrm{~h}^{-1}$ for scyphomedusa and hydromedusa. Some species were able to regulate oxygen consumption even below 10\% saturation, which indicates that these species do very well under low oxygen conditions. Other species are not as hypoxia-tolerant. The authors found critical oxygen tension values $\mathrm{P} c$ from $5.5 \mathrm{hPa}(\approx 3 \%$ saturation) in Muggiaea atlantica to $39.5 \mathrm{hPa}(\approx 19 \%$ saturation) in Euphys a flammea. They also tested the anoxia survival times and found values from $<2 \mathrm{~h}$ for E. flammea and Eutonina indicans to $>10 \mathrm{~h}$ for Aequorea victoria. The authors explained this high tolerance against hypoxia and anoxia with the ability for metabolic depression - the down regulation of metabolic demands. The ctenophore Mnemiopsis leidyi, a species originating from the east coast of the United States that has nowadays invaded the Black, Caspian, Mediterranean, Baltic and North Seas (in this sequence), shows a very sharp DO threshold (Keister et al., 2000). The species occurred at high densities at all $\mathrm{DO}>1-1.4 \mathrm{~mL} \mathrm{O}_{2} \mathrm{~L}^{-1}$, but was nearly absent at $<0.7 \mathrm{~mL} \mathrm{O}_{2} \mathrm{~L}^{-1}$.

In ctenophores, Grove and Breitburg (2005) found a significant reduction in growth at DO levels of 1.1 and $1.8 \mathrm{~mL} \mathrm{O}_{2} \mathrm{~L}^{-1}$, both in small ( 0.2 to $2.0 \mathrm{~mL}$ biovolume) and larger ( 8.0 to $17.6 \mathrm{~mL}$ biovolume) specimens. This phenomenon seems to occur especially at high prey densities. The same authors also found a significantly reduced egg production in Mnemiopsis leidyi when exposed to low DO. Growth rates in Chrysaora quinquecirrha did not deviate strongly between low DO and normoxic conditions. Gelatinous plankton are known to be predators of fish larvae and other zooplankton and, at the same time, compete with fish and fish larvae for the same zooplankton prey (Purcell and Sturdevant, 2001; Breitburg, 1994; Breitburg et al., 1997). It is argued that because of their higher tolerance against low oxygen (than e.g. finfish; Grove and Breitburg, 2005) they are predestined to take a dominant role in ecosystems with declining oxygen conditions. In particular, ctenophores seem to exhibit a high degree of predation pressure on copepods (Purcell and Decker, 2005). Shoji et al. (2005b) found that ingestion rates of fish larvae by moon jellyfish (Aurelia aurita) doubled with decreasing DO from 2.8 to $0.7 \mathrm{~mL} \mathrm{O}_{2} \mathrm{~L}^{-1}$. The reduced ability of many prey organisms to escape under hypoxic conditions most likely contributes to these results (Kodama et al., 2006; Dutil et al., 2007). Such opportunistic behaviour may well allow some jellyfish species to outcompete other organisms and control population levels of prey.

\subsection{Crustacea}

Crustacea belong to the most species-rich and diverse invertebrate taxa in the sea. The economically important species of decapods including lobsters, rock lobsters, shrimps, 
prawns and crabs usually have planktonic larval stages. Moreover, copepods and euphausiids dominate mesozooplankton communities in terms of abundance and biomass throughout the world ocean. They are of prime importance as a trophic link between marine primary production and upper trophic levels, including fish. We focus here on potential effects of hypoxia on crustaceans in the marine pelagic environment.

\subsubsection{Physiological effects}

The ability of certain zooplankton species to cross or even live in oxygen minimum zones is apparently linked to the presence and activity of enzymes of the anaerobic metabolism. The analysis of enzymatic activity of bulk zooplankton and of some dominant species revealed strong activity of both aerobic and anaerobic (LDH) metabolic components within the OMZ (Escribano, 2006). In a comparative study on the specific lactic dehydrogenase (LDH) activity in Euphausia mucronata and Calanus chilensis from the Humboldt Current upwelling system, the specific LDH activity in E. mucronata was two orders of magnitude higher than that of $C$. chilensis, consistent with E. mucronata's ability to conduct daily vertical migrations through the oxygen minimum zone, whereas $C$. chilensis is restricted to oxygenated waters above the OMZ (Gonzalez and Quiñones, 2002). In E. mucronata, body size was positively correlated with the specific LDH activity.

In the actively swimming Atlantic blue crab, Callinectes sapidus, which inhabits coastal and estuarine environments, where it often encounters hypoxia, combinations of hypoxic conditions and hypercapnia (increased carbon dioxide) severely reduced the activity of hemocyte phenoloxidase, an enzyme critical to antibacterial immune defence in crustaceans, implying that hypercapnic hypoxia compromises the ability of crustaceans to defend themselves against microbial pathogens (Tanner et al., 2006). Juvenile blue crabs Callinectes spp. showed significant decreases in feeding, growth, and moulting rates when exposed to prolonged episodes of hypoxia (10 to 28 days; Das and Stickle, 1993, 1994). Three European native species of freshwater crayfish, Austropotamobius pallipes, A. italicus and A. torrentium, demonstrated a disruption in the ion exchange process under hypoxia, but all tolerated very low oxygen concentrations for extended periods of time (Demers et al., 2006). Through physiological effects, hypoxia strongly enhances the rate of cadmium accumulation in gills and hepatopancreas of decapod shrimps; in particular, when heavy metal concentrations are low (Pierron et al., 2007). The main mechanism of interaction between hypoxia and heavy metal contamination seems to be related to chemical speciation.

Individuals of the marine cladoceran Moina micrura not acclimated to oxygen deficiency showed a severely reduced scope of activity (62.5-fold reduction over the range of 7 to $0.2 \mathrm{~mL} \mathrm{O}_{2} \mathrm{~L}^{-1}$ ), when subjected to hypoxic conditions
(Svetlichny and Hubareva, 2002). They stopped filtration and increased the time spent for swimming at concentrations of $0.5-0.6 \mathrm{~mL} \mathrm{O}_{2} \mathrm{~L}^{-1}$. However, individuals that had been acclimated to hypoxic conditions via long-term accumulation of haemoglobin were less affected. They showed no response at this oxygen concentration and survived apparently unharmed at levels as low as $0.14 \mathrm{~mL} \mathrm{O}_{2} \mathrm{~L}^{-1}$, maintaining their filtering activity (Svetlichny and Hubareva, 2002). In the freshwater cladoceran Daphnia magna, hypoxia can disrupt juvenoid hormone-mediated endocrine signalling (Gorr et al., 2006).

\subsubsection{Changes in spatial distribution}

Oxygen minimum zones (OMZ) have an important impact on the vertical distribution and migratory patterns of pelagic organisms (Saltzman and Wishner, 1997a, b; Wishner et al., 2008). Some species are virtually excluded from the OMZ, while others are able to stay or cross it (Longhurst, 1967; Herring et al., 1998; Gonzalez and Quiñones, 2002). Most zooplankton taxa show minimum abundances in the core of the OMZ, with higher abundances at the lower OMZ interface (Sameoto, 1986; Wishner et al., 1995; Böttger-Schnack, 1996; Saltzman and Wishner, 1997a). A local maximum in zooplankton abundance or biomass at the lower OMZ interface seems to be a unique feature of OMZ regions. Different species-specific tolerances to hypoxic conditions influence zooplankton community composition in areas affected by OMZ (Saltzman and Wishner, 1997a). In the Arabian Sea and in the California Current, zooplankton abundance and biomass decrease sharply when the oxygen concentration falls below $0.2 \mathrm{~mL} \mathrm{O}_{2} \mathrm{~L}^{-1}$ (Longhurst, 1967; BöttgerSchnack, 1996; Saltzman and Wishner, 1997a). Especially, deep-water oceanic species avoid the OMZ, while only a few species of copepods and euphausiids regularly occur within the OMZ. Often, individuals found in the core of the OMZ are dormant stages of species with ontogenetic or diel vertical migrations (Longhurst, 1967).

Similarly, the abundance of calanoid copepods, and the biomass of mesozooplankton in general, are severely reduced within the OMZ of the northern Benguela Current (Verheye et al., 2005; Auel and Verheye, 2007). The dominant copepod Calanoides carinatus shows a bimodal vertical distribution with parts of the population either concentrated in the surface layer $(0-60 \mathrm{~m})$, or copepodids $\mathrm{C} 5$ diapausing below $400 \mathrm{~m}$ depth; apparently avoiding the OMZ in between (Auel et al., 2005; Verheye et al., 2005; Auel and Verheye, 2007). Abundances of other calanoid copepods are higher at the surface and below $300 \mathrm{~m}$ as compared to the centre of the OMZ. Most euphausiids and some copepods avoid the core of the OMZ with less than $0.1 \mathrm{~mL} \mathrm{O}_{2} \mathrm{~L}^{-1}$ (Sameoto, 1986; Sameoto et al., 1987; Saltzman and Wishner, 1997b). Increasing abundances of copepods and euphausiids below the OMZ indicate that the OMZ acts as a barrier for some species, although specifically adapted 
species regularly migrate through the OMZ (Saltzman and Wishner, 1997b; Auel and Verheye, 2007, for Euphausia mucronata in the Humboldt Current see Escribano et al., 2009). Among the specialists that regularly inhabit the OMZ is Rhincalanus nasutus (Castro et al., 1993; Sameoto, 1986) and non-calanoid copepods of the genus Oncaea (BöttgerSchnack, 1996). In the Benguela Current, hypoxia-tolerant copepod species that inhabit the OMZ include Pleuromamma robusta, Heterorhabdus sp., Aetideopsis carinata and again Rhincalanus nasutus (Auel and Verheye, 2007).

In the coastal upwelling system of the Humboldt Current off Chile, key copepod and euphausiid species are affected in their vertical distribution and migrating behaviour by the extent of the OMZ between 60 and $200 \mathrm{~m}$ depth. Several abundant species appear to be constrained by the OMZ and restricted to the upper $50 \mathrm{~m}$ layer, whereas others temporarily or permanently inhabit the OMZ and substantially contribute to the vertical flux of organic carbon from the euphotic zone through active vertical migration (Escribano, 2006). Among the few species permanently living in the OMZ and performing diel vertical migrations only within the OMZ are the copepods Eucalanus attenuatus and Eucalanus inermis as well as the euphausiids Euphausia distinguenda, Stylocheiron affinis and Nematoscelis megalops. Four more euphausiid species, i.e. Euphausia mucronata, E. eximia, E. recurva, and E. tenera, perform extended diel vertical migrations, feeding at night in the upper OMZ (60-100 m) and descending below the OMZ during daytime. In contrast, the copepods Pleuromamma gracilis and Euchaeta spp. spend the night time below the OMZ and migrate upwards into the OMZ during daytime, thus conducting a kind of inverse diel vertical migration (Escribano, 2006).

Because of their abundance, biomass and vertical migration behaviour, the large-sized copepod Eucalanus inermis and the krill species Euphausia mucronata are especially important for the transport of organic carbon from the euphotic zone into the OMZ. There is a substantial daily exchange of $>75 \%$ of total zooplankton biomass between the euphotic layer and the OMZ. Eucalanus inermis can actively exchange more than $10 \mathrm{~m} \mathrm{C} \mathrm{m}^{-3}$ between the base of the thermocline (30-60 m) and the deeper OMZ layer (60-200 m), whereas Euphausia mucronata contributes nearly $1 \mathrm{~g} \mathrm{C} \mathrm{m}^{-3}$ to the daily exchange from the upper $200 \mathrm{~m}$ to deeper layers (Escribano, 2006). The migration of zooplankton in and out of the OMZ could be a very efficient mechanism to incorporate freshly produced organic matter into the OMZ. Vertical migrations, population dynamics, life-cycle strategies and metabolic adaptations of key zooplankton species may contribute to the maintenance and persistence of the oxygendepleted water mass (Escribano, 2006).

Increasingly hypoxic conditions and the expansion of the OMZ could lead to cascading effects on benthic and pelagic ecosystems, including habitat compression and community reorganization (Bograd et al., 2008). Mesopelagic organisms such as crustaceans and myctophid fishes that live in the upper boundary region of the OMZ or perform diel vertical migrations to feed in the surface layer at night may be affected (Childress and Seibel, 1998), with consequent impacts on their epipelagic prey species.

\subsubsection{Reproduction}

Studies on the effects of hypoxia on crustacean reproduction have focused on the egg production, hatching success and viability of copepods. Short exposure to near anoxia (0.04 to $0.08 \mathrm{~mL} \mathrm{O}_{2} \mathrm{~L}^{-1}$ ) or a combination of anoxia with increased sulfide concentrations $\left(\approx 1 \mathrm{mmol} \mathrm{L}^{-1}\right)$ induced quiescence in the eggs of the planktonic copepod Acartia tonsa, but did not affect egg viability and subsequent growth and survival after restoration of normoxic conditions (Invidia et al., 2004). However, exposure times $\geq 15$ days caused significant declines in hatching and strong reductions in life expectancy. In another study, eggs of $A$. tonsa stopped hatching at oxygen concentrations lower than $0.07 \mathrm{~mL} \mathrm{O}_{2} \mathrm{~L}^{-1}$, but were not killed since they resumed hatching when transferred to normoxic seawater (Lutz et al., 1994). Experimental results obtained by various authors (Lutz et al., 1992, 1994; Roman et al., 1993; Marcus and Lutz, 1994; Marcus et al., 1997; Invidia et al., 2004) differ slightly regarding the concentration of oxygen that induces quiescence and the maximum survival times for eggs exposed to hypoxic concentrations. In general, maximum survival time of $A$. tonsa eggs under anoxic conditions ranged from 20 to $>32$ days, related to variations in the developmental stages of the eggs and differences in the genetic and/or environmental histories of the females producing the eggs (Marcus and Lutz, 1994; Marcus et al., 1997; Invidia et al., 2004).

In Acartia bifilosa, a dominant copepod species in the Baltic Sea, low oxygen concentrations $<0.17 \mathrm{~mL} \mathrm{O}_{2} \mathrm{~L}^{-1}$ induced dormancy in the eggs. Hatching was prevented by anoxic conditions, but subitaneous eggs survived well under these conditions for 10 to 12 months depending on the temperature. After 10 months of anoxia at $4{ }^{\circ} \mathrm{C}$, approximately $40 \%$ of the eggs still hatched, when brought back to normoxic conditions (Katajisto, 2004). Since copepod recruitment from benthic eggs is prevented during anoxic events, the duration, area, and timing of anoxic events, as well as the species-specific tolerance of the eggs to low oxygen concentrations, will affect copepod population dynamics and zooplankton community composition in general (Roman et al., 1993; Katajisto, 2004). In contrast, temporarily anoxic conditions might even protect benthic eggs and resting stages from predation (McQuoid et al., 2002; Katajisto, 2004).

Besides hatching success and viability, egg production rate can also be affected by hypoxic conditions. At reduced dissolved oxygen concentrations of $1.5 \mathrm{~mL} \mathrm{O}_{2} \mathrm{~L}^{-1}$, egg production of $A$. tonsa, but not survival, was significantly reduced as compared to normoxic controls (Marcus et al., 2004). At $0.7 \mathrm{~mL} \mathrm{O}_{2} \mathrm{~L}^{-1}$, both adult survival and egg production were significantly reduced. These results suggest that, besides 
direct lethal effects of hypoxia, sub-lethal responses such as reduced egg production can have important repercussions on population and community dynamics of marine copepods and food webs (Marcus et al., 2004).

\subsection{Molluscs/squid}

Information on oxygen requirements or hypoxia tolerance of pelagic molluscs is scattered. A reason may be that these animals occur more in open waters and are not as amenable to experiments as other species. On the other hand we observe an increasing abundance of some squid species. Catches of squid have tripled during the last 30 years (MoralesBojorquez et al., 2001; FAO, 2010a) suggesting an increasing role in pelagic foodwebs of neritic and oceanic ecosystems. Squid seems to be more tolerant against low oxygen than many other pelagic organisms, even though their burst swimming method requires more energy than other modes of locomotion, such as swimming in fish (Pörtner and Zielinski, 1998). Their oxygen consumption rises during exercise to fivefold above resting level (Hoeger et al., 1987). They are frequently found in the OMZ, where they can remain for long periods during the day (Gilly et al., 2006) floating around without movement and waiting for prey.

A critical oxygen partial pressure for squid seems to be 19\% saturation (citation $29-30 \mathrm{~mm} \mathrm{Hg}$; Hunt and Seibel, 2000). Howell and Simpson (1994) found reduced catches below a threshold value of $2.1 \mathrm{~mL} \mathrm{O}_{2} \mathrm{~L}^{-1}$ and Roberts and Sauer (1994) suggested $3 \mathrm{~mL} \mathrm{O}_{2} \mathrm{~L}^{-1}$ to be the threshold for squid to avoid low oxygen areas. However, sensitivity is size-related, showing a higher oxygen consumption rate and steeper decline of consumption at low DO for juveniles than for sub-adults. A significant reaction of the organism is observed at $25 \%$ saturation $(40 \mathrm{~mm} \mathrm{Hg})$, but a dramatic decline in respiration is found only below $12 \%$ saturation $(20 \mathrm{~mm} \mathrm{Hg})$. This is close to the tolerance values Zielinski et al. (2000) found for Lolliguncula brevis. As a measure of the vulnerability to hypoxia, the onset of anaerobic metabolism can be used; it started at 49 to $41 \%$ saturation (9.4 to $7.9 \mathrm{kPa}$ ). The absolute DO limit for the species was identified at $13.2 \%$ saturation $(2.8 \mathrm{kPa})$. Seibel et al. (1997) found even lower critical values down to $2-12 \%$ saturation (3-19 $\mathrm{mm} \mathrm{Hg}$ ). Direct field observations show the sensitivity of some squid to low oxygen. Rabalais et al. (2001) found squid in Remotely Operated Vehicle records only where DO was above $1.4 \mathrm{~mL} \mathrm{O}_{2} \mathrm{~L}^{-1}$, and Roberts (2005) showed that Chokka squid (Loligo vulgaris) selects its spawning ground on the eastern Agulhas Bank where temperature and oxygen are optimum for the embryonic stages with ranges of temperatures between 11 and $20^{\circ} \mathrm{C}$ and oxygen above $3 \mathrm{~mL} \mathrm{O}_{2} \mathrm{~L}^{-1}$. Young stages seem to be more vulnerable to hypoxic conditions as shown by Hunt and Seibel (2000), who found juvenile squid Gonatus onyx at shallower depths with DO around $1 \mathrm{~mL} \mathrm{O}_{2} \mathrm{~L}^{-1}$ while the adults went deeper into the $\mathrm{OMZ}$ with DO less than $0.5 \mathrm{~mL} \mathrm{O}_{2} \mathrm{~L}^{-1}$. It has been argued by different authors that the decline in oxygen concentration in the Eastern Pacific has induced an extension of the distribution range of the jumbo squid (Dosidicus gigas). Landing of the species has increased fivefold over the last decade (FAO, 2010a) now supporting a large fishery.

Vetter et al. (2008) assume that the shoaling of the OMZ may provide refuge from highly mobile predators such as mako sharks and thus supports an increase of squid biomass. Squid, especially jumbo squid, has an enormous growth potential (Mejía-Rebollo et al., 2008) supporting a fast expansion of its distribution area. The extending OMZ serves as an increasing refuge space for hypoxia-tolerant mesopelagic fish species and supports this rapid biomass increase in jumbo squid off Chile and California (Field et al., 2007; Field, 2008). Argúelles et al. (2008) also argue that such increased food availability leads to a larger size-at-maturity in D. gigas and thus enhances the reproductive potential.

\subsection{Fish}

The physiological impact of low oxygen concentrations on different life stages of fish is well studied, and this knowledge has been used e.g. in aquaculture to optimise the artificial production processes of these animals. Hypoxia is a highly effective inducer of hatching in mature Atlantic salmon eggs when applied less than 1 month prior to normal hatching (Oppen-Berntsen et al., 1990). This kind of stimulus is frequently used in aquaculture to synchronise hatching of larvae. We also know that fish need well aerated water to remain healthy and use food efficiently for optimal growth. However, intensive aquaculture conditions are extreme and in some settings fish do not have any possibility to escape hypoxic waters. Behaviour and reaction to low oxygen in the natural environment will be different. Kramer (1987) stated four principal categories of behavioural response to reduced dissolved oxygen in the environment: (1) changes in activity, (2) increased use of air breathing, (3) increased use of aquatic surface respiration, and (4) vertical or horizontal habitat changes. Not all of these categories are suitable for marine fish, responses 2 and 3 are more frequently observed in freshwater fishes. However change in activity such as swimming speed and growth and avoidance of low oxygen conditions by changing the habitat have been observed in the marine environment quite frequently. We concentrate here on marine fish species but include some data from freshwater species for comparative reasons.

\subsubsection{Physiological effects}

The first physiological reaction of fish to a decline of oxygen concentration is through compensation by hyperventilation (Berschick et al., 1987). Consequences can include a reduction in growth rate, as shown for demersal fish such as turbot (Scophthalmus maximus) or sea bass (Dicentrarchus labrax). These fish cope with low-oxygen conditions 
by reducing one of their physiological activities, growth. The underlying mechanism is likely to be a reduction in food intake (Boeuf et al., 1999; Pichavant et al., 2001). A decrease in ingestion may reduce the energy demands and therefore the oxygen requirements. Oxygen uptake in larval Anchoa mitchilli, Archosargus rhomoidalis and Achirus lineatus was directly related to their weight (Houde and Schekter, 1983). King (1977) found a relationship between survival of Sardinops sagax larvae and DO combined with temperature. However, this correlation, albeit evident when combined with temperature, was weak. This may be attributed to the limited number of experimental treatment levels using only oxygen concentrations of $1.5,3.5$ and $5.2 \mathrm{~mL} \mathrm{O}_{2} \mathrm{~L}^{-1}$. As a consequence, the critical range in oxygen concentration, found to be below $1.5-2 \mathrm{~mL} \mathrm{O}_{2} \mathrm{~L}^{-1}$ in other experiments (e.g. Keister et al., 2000; Miller et al., 2002) was covered only marginally in his experiments.

From other experiments it is known that $S$. sagax shows a low temperature coefficient $\mathrm{Q}_{10}$ indicative of a high eurythermy (van der Lingen, 1995). Lowest non-feeding swimming respiration rate of the species was $4.3 \mu \mathrm{mol} \mathrm{O}_{2} \mathrm{~g}^{-1} \mathrm{~h}^{-1}$ which is ca. $50 \%$ more compared to other fish species (Brett et al., 1979). Filter-feeding was found to be energetically cheaper than particulate feeding, which leads to the assumption that at a decreasing food concentration fish may have to switch from filter to particulate feeding and hence increase their oxygen consumption to catch the same amount of food. Physiological experiments examining responses to low oxygen concentration have primarily been conducted on adult fish. A direct influence of anoxic conditions on the physiology has been observed in electric eels (Crampton, 1998). Field observations showed that the fish avoided crossing areas with low oxygen concentrations of 2.1-2.8 $\mathrm{mL} \mathrm{O}_{2} \mathrm{~L}^{-1}$. In many fish species, hypoxia leads to an increased ventilation frequency indicating a negative effect on their physiology (Powell and Perry, 1997). Plante et al. (1998) investigated the hypoxia tolerance of adult Atlantic cod and found an $\mathrm{LC}_{50}$ (Lethal concentration where $50 \%$ of organisms survive) at $21 \%$ saturation and no survival at $10 \%$. Carp, normally a fish that is adapted to low environmental oxygen concentrations, showed a decrease of its critical DO (normally $\approx 2.7 \mathrm{~mL} \mathrm{O}_{2} \mathrm{~L}^{-1}$ ) when exposed to higher salinities in brackish waters (De Boeck et al., 2000). Cichlids reared under normal oxygen conditions had higher metabolic rates than those reared under hypoxic conditions (Chapman et al., 2002). Kunzmann (personal communication, 2008) performed oxygen uptake and hypoxia tolerance experiments with young horse mackerel. The species was able to survive to $10 \%$ DO saturation over a period of several hours and recovered within $2 \mathrm{~h}$ to repeat the exercises.

\subsubsection{Reproduction}

Considerable work has been done on combined impacts of temperature and low oxygen on early life stages of commercially important freshwater species such as rainbow trout or carp. In their review on the embryology in fish, Depeche and Billard (1994) state that "Eggs are usually laid in an environment where oxygen is available". However, in some ecosystems fish may have increasing problems to find enough oxygenated waters to spawn or for their eggs to develop properly (Messieh and Rosenthal, 1989; Ekau and Verheye, 2005; Kreiner et al., 2009). Extreme hypoxia may inhibit spawning activity (Wang et al., 2008), while moderate hypoxia can influence egg development and cause early hatching, e.g. in cultured coregonid fish (Czerkies et al., 2001). It triggers the release of hatching enzyme in late-stage-egg embryos. When Atlantic salmon were exposed to a partial oxygen pressure of $5 \mathrm{~mm} \mathrm{Hg}$ ( $\approx 3 \%$ saturation; Oppen-Berntsen et al., 1990), all eggs hatched within a 2-h time span instead of the normal period of up to one week. This procedure has to be applied carefully not to damage the embryos. The opposite effect can be achieved when maintaining the eggs under high oxygen pressure. Hatching is then delayed indefinitely (Hagenmaier, 1972). Under prolonged sub-lethal hypoxic conditions, herring embryos were weakened and negatively impacted in their development, leading to significantly higher rates of malformation (Braum, 1973; Shang and Wu, 2004). The hatching length of the embryos decreased from $8.4 \mathrm{~mm}$ at $100 \%$ saturation to $6.1 \mathrm{~mm}$ at $<50 \%$ (Braum, 1973). Weaker larvae would reduce the survival chance for the year classes. Widmer et al. (2006) found significantly reduced swimming abilities in zebrafish reared under hypoxic conditions and MacGregor and Houde (1996) found that most anchovy eggs and larvae in the main stem of midChesapeake Bay ( $>20 \mathrm{~m}$ water depth) were above the pycnocline, when below-pycnocline DO was $<1.4 \mathrm{~mL} \mathrm{O}_{2} \mathrm{~L}^{-1}$. When Thomas et al. (2006) analysed the impact of low DO on Atlantic croaker (Micropogonias undulatus) they found a significant impairment of ovarian growth and a decrease in the production of fully grown oocytes.

Oxygen demand changes significantly during ontogenesis. Pfeiler (2001) observed an increase in sensitivity to hypoxia during the 10-day metamorphic period of leptocephalus larvae in the bonefish Albula sp. Metamorphosis is a highly physiologically demanding period in the early development of a fish, requiring a lot of oxygen. The larvae do not feed during that time but use their own reserves of lipids and carbohydrates; yet oxygen demand is twice as high as normal, which makes larvae vulnerable to hypoxic conditions. Resistance of early larval stages against low oxygen is better in species with demersal eggs, e.g. herring, than those with pelagic eggs, e.g. plaice. These differences in resistance level out at later development stages (De Silva and Tytler, 1973). Metamorphosis is the time where flat fishes change to a bottom mode of life and where coral reef fishes select 
their future home reef and settle in their new habitat. As adults, several coral fish genera (Gobiodon, Paragobiodon and Caracanthus) show a well-developed hypoxia tolerance down to $3 \%$ air saturation to overcome low oxygen during night in their micro-habitats or they switch to air-breathing at low tides (Nilsson et al., 2007a). During their larval phase, especially during the pre-settlement phase, coral fish such as the damselfishes Chromis atripectoralis and Pomacentrus amboinensis show extremely high rates of oxygen uptake and very low hypoxia tolerance (Nilsson et al., 2007b). Obviously these species change their metabolism during their transition from a planktonic mode of life in an oxygen saturated environment to a demersal mode of life under at least temporary hypoxic conditions.

\subsubsection{Changes in spatial distribution}

The most obvious effect of hypoxia on the spatial patterns of fish is in their vertical and/or horizontal distribution. Abundances of fish larvae and their staple food copepod nauplii were lower throughout the water column when bottom-layer DO was $\leq 1.4 \mathrm{~mL} \mathrm{O}_{2} \mathrm{~L}^{-1}$ (Keister et al., 2000). Densities of naked goby larvae were less than one-third of those observed at $>1.4 \mathrm{~mL} \mathrm{O}_{2} \mathrm{~L}^{-1}$. While the vertical distribution of juvenile bay anchovies (Anchoa spp.) was generally restricted to the upper water layer with $>1.75 \mathrm{~mL} \mathrm{O}_{2} \mathrm{~L}^{-1}$, some specimens entered waters with $\mathrm{DO}$ down to $0.7 \mathrm{~mL} \mathrm{O}_{2} \mathrm{~L}^{-1}$ (Taylor et al., 2007). These "outliers" were obviously looking for food in near bottom water layers. While invertebrate zooplankton passed the well developed OMZ in the shallow Hoodsport fjord, USA, to reach the surface waters $<20 \mathrm{~m}$, fish remained below the base of the OMZ ( $35 \mathrm{~m})$ suggesting that the OMZ affects fish in their vertical migration and thus functions as a refuge for prey organisms (Parker-Stetter and Horne, 2009).

In Baltic cod the vertical distribution of eggs and larvae is highly correlated with the hydrographic situation in the water column. The suitable habitat for the early stages is constrained by the low salinity in the top layer and low oxygen in the bottom layers. Grønkjaer and Wieland (1997) could not find Baltic cod larvae in layers deeper than $75 \mathrm{~m}$. The oxygen concentration below this depth drops rapidly to $<2 \mathrm{~mL} \mathrm{O}_{2} \mathrm{~L}^{-1}$ (Nissling, 1994), and the authors argued that oxygen limits the depth distribution of these larvae. Buoyancy of the eggs is predetermined in the ovary of the mother fish by their lipid and water content, but after fertilisation the density of the eggs may also change with changing permeability of the chorion (Nissling and Vallin, 1996) and thus influence egg vertical distribution.

Ekau and Verheye (2005) worked in open shelf waters off Namibia on the vertical distribution of fish eggs and larvae and the relationship between their abundance and oxygen concentration. Results indicated that low oxygen in waters deeper than 40 to $60 \mathrm{~m}$ may significantly impact the vertical distribution of fish species. At a threshold value of about
2.5 to $3 \mathrm{~mL} \mathrm{O}_{2} \mathrm{~L}^{-1}$ larval abundance dropped sharply and their distribution was significantly more dependent on DO than on temperature or depth. The larval stage is known to be the most sensitive to low DO levels. Concentrations of 0.4 to $1.3 \mathrm{~mL} \mathrm{O}_{2} \mathrm{~L}^{-1}$ may cause a $50 \%$ mortality of larvae and juvenile fish, depending on the species and its lifestyle, with pelagic species being more sensitive than demersal ones (Miller et al., 2002). Survival time decreased about threefold over the metamorphic period in an Albula species with a leptocephalus larva (Pfeiler, 2001). Juvenile weakfish (Cynoscion regalis) followed the diel-cycling of low oxygen fronts in an estuary by avoiding areas of $\mathrm{DO}<1.4 \mathrm{~mL} \mathrm{O}_{2} \mathrm{~L}^{-1}$ (Tyler and Targett, 2007). The critical saturation increases with temperature in line with the concept of interacting thermal windows and hypoxia tolerance outlined in Sect. 2. In cod, the threshold moved from $16.5 \%$ at $5{ }^{\circ} \mathrm{C}$ to $30 \%$ at $15^{\circ} \mathrm{C}$ (Schurmann and Steffensen, 1997), and D'Amours (1993) found $2.4 \mathrm{~mL} \mathrm{O}_{2} \mathrm{~L}^{-1}$ as a threshold value for adult cod at temperatures above $4^{\circ} \mathrm{C}$. An oxygen saturation of $70 \%$ seems to be a threshold above which substantially higher abundances of cod are encountered (Chabot and Claireaux, 2008). Fish larvae apparently aggregate along thermoclines, where both temperature and oxygen saturation drop with depth (Gray and Kingsford, 2003).

In the Northern Benguela upwelling system, the temperature within the thermocline decreases rapidly to less than $15-17^{\circ} \mathrm{C}$ coinciding with a drop in DO to only $0.5-$ $1.5 \mathrm{~mL} \mathrm{O}_{2} \mathrm{~L}^{-1}$, which is equivalent to oxygen saturation levels of 9-27\% (Ekau and Verheye, 2005). This situation is encountered at water depths around $40-50 \mathrm{~m}$ resulting in a separation of a surface layer that is fairly populated with fish larvae and a poorly populated deeper layer at water depth $>40 \mathrm{~m}$. In particular, sardine and anchovy larvae strongly prefer the well-oxygenated upper $40 \mathrm{~m}$ (Kreiner et al., 2009).

\subsubsection{Growth}

Growth in fish is a physiological process that is closely related and strongly influenced by temperature, food availability and developmental stage. Hence, decreased DO in the water leads to constraints in growth shown as a correlation between growth performance and oxygen concentration by different authors (e.g. Carlson et al., 1980; Brett and Blackburn, 1981; Chabot and Dutil, 1999; Braun et al., 2006). The growth rates in American winter flounder (Pseudopleuronectes americanus) kept in hypoxic waters were less than $50 \%$ of those kept under normoxic conditions (Bejda et al., 1992). Similarly, moderate hypoxic conditions caused a $20 \%$ reduction in growth of turbot (Boeuf et al., 1999). Chabot and Claireaux (2008) confirmed this threshold in laboratory studies and demonstrated that growth and food ingestion of Atlantic cod were significantly reduced below $70 \%$ saturation.

There is a significant impact of low oxygen on the reproduction and growth of the Gulf killifish (Fundulus grandis) 
(Landry et al., 2007). The authors explained this impact with the reduction of overall energy expenditure and an alteration of specific hormonal pathways that mediate gamete production. They found the sex steroid hormone E2 being $50 \%$ reduced in females exposed to low oxygen, a consequence of this being $\approx 30 \%$ smaller gonads. The daily egg production at low oxygen dropped to about $26 \%$ of the level under normoxic conditions!

Pichavant et al. (2001) compared the growth of European sea bass under hypoxic conditions but fed to satiation with another group of specimens reared in normoxic conditions but with restricted rations. They found no significant differences in growth and explained that the decrease in food uptake would be an indirect mechanism to save energy in a hypoxic environment, and reduced growth would thus be an indirect effect. Feeding experiments by Jordan and Steffensen (2007) showed that cod, fed under normoxic conditions at a food rate of 2.5 and $5 \%$ of body weight, used 40 and $55 \%$ of their oxygen uptake for specific dynamic action, respectively, while they used $69 \%$ under hypoxic conditions leaving much less oxygen for other metabolic activities. Similar results were found by Bejda et al. (1987) for red hake Urophycis chuss, where especially younger stages increased their swimming activity to escape low oxygen waters and all stages reduced food search activities with decreasing oxygen content.

\subsubsection{Swimming behaviour and low oxygen avoidance}

Besides physiological reactions to low DO, larval and adult fish have developed a number of behavioural adaptations to cope with low oxygen conditions. Freshly hatched trout larvae, for example, decrease their number of movements by $60 \%$ when exposed to hypoxia to reduce their oxygen consumption and total metabolism (Ciuhandu et al., 2007). Juvenile white sturgeon (Acipenser transmontanus) decreased their activity by $70 \%$ when exposed to moderate hypoxia (Crocker and Cech, 1997). In adult carp, the decrease in activity was similar, with a gradual decrease, and a plateau was reached after 90-120 min of exposure to anoxia (Nilsson et al., 1993). Restricted mobility during hypoxia is probably a strategy to reduce oxygen demand and focus on vital functions rather than on locomotive activity. Some studies have reported an increase in activity with moderate hypoxia e.g. for sand goby Pomatoschistus minutus (Petersen and Petersen, 1990) or adult brook trout Salvelinus fontinalis (Tang and Boisclair, 1995), but these responses can alternatively be explained as escape responses to hypoxia (Petersen and Petersen, 1990).

Various investigations from different areas in the world have shown that low DO levels have a severe impact on the composition and abundance of adult and larval fish fauna. Westernhagen and Dethlefsen (1983) and Dethlefsen and Westernhagen (1983) reported on dramatically reduced fish catches following a low-oxygen $\left(1.2-1.5 \mathrm{~mL} \mathrm{O}_{2} \mathrm{~L}^{-1}\right)$ water intrusion in the North Sea. A distinct stratification extended over several thousand square kilometres, inhibiting the aeration of deeper waters from the oxygenated surface waters. Fish catches were reduced to only $2-10 \mathrm{~kg} \mathrm{~h}^{-1}$ compared to $720-900 \mathrm{~kg} \mathrm{~h}^{-1}$ at a location with normoxic water (2.7$\left.3 \mathrm{~mL} \mathrm{O}_{2} \mathrm{~L}^{-1}\right)$. Direct video observations showed that all "mobile" fish species such as herring, sprat, cod, etc. had fled the area, while a few strongly bottom-related species, e.g. flat fish, remained in the affected area and were affected by high mortality.

Howell and Simpson (1994) found a significant correlation between the mean catch and the mean species number with bottom dissolved oxygen concentrations in Long Island Sound showing a steep increase in catches at 2$2.9 \mathrm{~mL} \mathrm{O}_{2} \mathrm{~L}^{-1}$ relative to lower oxygen values, indicating movements of the fish along suitable oxygen gradients. Similar behaviour was found for large mouth bass by Burleson et al. (2001). They found a close relationship between the site selection of the fish and oxygen saturation. At ca. $24{ }^{\circ} \mathrm{C}$ the fish actively selected areas with $>27 \%$ oxygen saturation $\left(1.7 \mathrm{~mL} \mathrm{O}_{2} \mathrm{~L}^{-1}\right)$ and avoided areas with lower levels. Preferred DO saturation was around $46 \%$, corresponding to an oxygen concentration of $2.8 \mathrm{~mL} \mathrm{O}_{2} \mathrm{~L}^{-1}$. This appears to be a common rule, when compared with data of Spoor (1984) and Wannamaker and Rice (2000).

Cod respond very clearly to short term declines in oxygen saturation (e.g. from $100 \%$ to $20 \%$ ) through changes in swimming behaviour (Johansen et al., 2006). The fish initially increased its swimming speed significantly (29\%) but then decreased swimming speed by $54 \%$. Specimens showed severe stress symptoms during these experiments, reflected in elevated cortisol and blood lactate values. Even if these experiments do not give a full picture of avoidance behaviour, as no area of refuge was available in the experimental setup, the results indicate that low oxygen levels are a stress situation for cod from which it tries to escape by increased swimming activity. The secondary response in reduced swimming speed was due to limited oxygen availability. Similar results were found by Herbert and Steffensen (2005). Weltzien et al. (1999) showed that if fish have a choice to select suitable oxygen concentrations they go for the high concentrations. In an oxygen-stratified setup silverside yolk-sac larvae (Menidia beryllina) were significantly attracted towards the upper well saturated layer when oxygen concentration in the lower layer was $<2.1 \mathrm{~mL} \mathrm{O}_{2} \mathrm{~L}^{-1}$. They remained in the lower layer only when the water was saturated. Similar results were shown for larvae of bay anchovy (Anchoa mitchelli) and naked goby (Gobiosoma bosc) in a stratified water column where both species exhibited a significant response to low DO (Breitburg, 1994). Good larval survival was found at $2.1 \mathrm{~mL} \mathrm{O}_{2} \mathrm{~L}^{-1}$ in naked goby and at $1.5 \mathrm{~mL} \mathrm{O}_{2} \mathrm{~L}^{-1}$ in bay anchovy, whereas below these concentrations, larval mortality increased rapidly. 


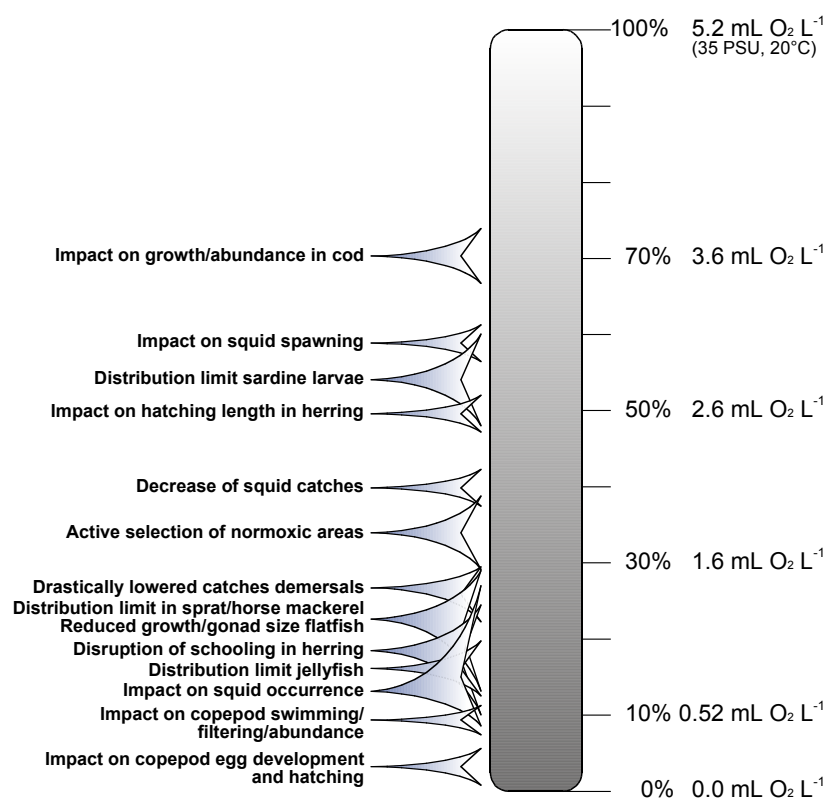

Fig. 3. Behaviour and physiology responses of marine organisms to various oxygen saturation levels. The graph summarizes and illustrates the information given in Table 2 .

\subsubsection{Schooling}

Schooling is an important behavioural feature in pelagic fish that starts during transformation at the end of the larval stage; e.g. in Pacific mackerel at 10-15 mm (Matsuura and Hewitt, 1995). There are several advantages for the organisms to form and join schools, e.g. saving swimming energy (Herskin and Steffensen, 1998) or predator deterrence. Schooling behaviour can be affected by decreasing oxygen concentrations (Moss and MacFarland, 1970). Anchovy (Engraulis mordax) react significantly with an increase in swimming velocity when oxygen concentration decreases rapidly. However, with a slow decrease in oxygen level, anchovies did not show any change in swimming speed. The mode of life also plays a role in the reaction to oxygen decrease. Sole (Solea solea) or sluggish eelpouts decrease their activity when exposed to hypoxia (Fischer et al., 1992; Dallavia et al., 1998) while fast swimming pelagic fish such as the skipjack tuna increase their speed (Dizon, 1977; Bushnell and Brill, 1991) in order to escape the area. Schools of Atlantic herring showed an increase in swimming speed at low oxygen saturation (15$34 \%$ ) (Domenici et al., 2000). The authors hypothesized that the fishes increase their swimming speed in order to rapidly escape from the unfavourable environment. Pihl et al. (1991) observed this type of response in adult cod. On the other hand schooling itself may cause decreased oxygen levels in the central and back part of the school just by the respiration of the organisms in the school and it may be a limiting factor for the size of a school (Steffensen, 1995; Domenici et al., 2000). From several studies it can be concluded that lower oxygen induces a wider spacing of the fish in the school leading to a looser network that may result in a complete disruption of the school. Domenici et al. (2000) observed such school disruption in herring at 10-25\% oxygen saturation.

The overall impact of hypoxia on schools of pelagic fish, such as herring, is complex. As the dimensions of schools increase, O-turning, used in changing position within the school, is suppressed while shuffling rate remains constant. This behaviour results in increased overtaking of position within the school, perhaps leading to an increase in overall energy expenditure (Domenici, 2002). The increase in spatial extent of the school leads to a larger inter-individual distance causing lower communication and higher vulnerability to predators. In the extreme case, i.e. complete disruption of the school, reproduction success may be influenced by reduced probability of egg fertilisation.

\subsubsection{Concluding remarks on taxonomic groups}

Our knowledge of the effects of oxygen concentration on marine pelagic organisms is best for bony fishes. Table 2 gives some examples of oxygen consumption and hypoxia tolerance levels for different species. More data are available from Thuesen and Childress (1994), Miller et al. (2002), and Vaquer-Sunyer and Duarte (2008). The focus of Table 2 is on the variety of impacts deriving from changing or low oxygen conditions in the pelagic environment. We learnt from Sect. 2 that standard metabolism is strongly influenced by the ambient temperature and temperature tolerance is a function of oxygen concentration. Species have optimum ranges with regard to both environmental parameters (Alderdice and Forrester, 1968; Brett and Groves, 1979; Pörtner and Lannig, 2009) and they seek areas with conditions close to these optima as far as possible. Any deviation from the optima will increase energy demand. Figure 3 summarizes the reaction of different species and stages to decreasing DO. The first reaction of the individuals is an increase in activity in order to leave and avoid unfavourable areas, resulting in a decrease in abundance. If the organism is forced to remain under unfavourable conditions, secondary effects may occur such as reduced growth or gonad size. These reactions can be observed at 50 to $70 \%$ saturation. Spawning products may suffer increased mortality and hatched larvae may be weaker because of reduced feeding and elevated energy demand. Below 30\% saturation, pelagic organisms are more vulnerable and respond with changes in behaviour, reduced growth, higher vulnerability to predation and increased mortality. Ultimately, persistence of unfavourable conditions may result in the disappearance of the species from the system.

\section{Ecological effects}

Besides direct impacts on the physiology and behaviour of individuals, hypoxia can also cause effects through changes 
in the biotic environment, i.e. changes in prey availability, prey size or predation risk. Changes in species composition are a common response to changing oxygen conditions, the strength of which depends on the duration and amplitude of the hypoxic events. Diaz (2001) listed 43 areas/ecosystems with aperiodic, periodic, or persistent hypoxia sometimes resulting in significant changes of the benthic fauna.

Several authors argue that oxygen concentration is shaping the communities of fish and other aquatic animals (e.g. Maes et al., 1998; Rosenberger and Chapman, 1999). Intensive work has been done on estuaries and benthic/demersal communities where the impact of hypoxia forces species to adapt quickly or perform avoidance migrations (Pihl et al., 1991; Keister et al., 2000; Renaud, 1986). The complete species inventory of a community may be substituted by hypoxiatolerant species from neighbouring habitats (Stevens et al., 2006). Evidence for the impact of low oxygen on pelagic communities in open coastal and offshore waters is scarce. A shift in the structure and composition of fish larvae over the last decade could be correlated to changes in the extension of the OMZ along the northern Namibian coast (Ekau and Bröhl, 2008). An example may also be seen in the extension of the distribution range of the jumbo flying squid Dosidicus gigas in the northeastern Pacific where hake is supposed to be dispersed and out-competed (Holmes et al., 2008). Jumbo squid show a high tolerance against low oxygen and have been observed by means of direct video observations to remain motionless for hours in the OMZ during daytime, interrupted only for feeding on myctophids, their main prey (Gilly et al., 2006). The ability to use the OMZ for shelter and feeding gives advantage to the squid over other predatory species such as horse mackerel, hake or tuna. With the extending OMZ in the eastern Pacific, jumbo flying squid is able to extend its distribution area polewards (Gilly, 2005) and outcompete other species.

Hypoxia can lead to a decoupling of predator-prey interactions and, thus, change trophic fluxes through food webs (Taylor and Rand, 2003). In a study on anchovies and copepods, hypoxia caused a spatial separation between plankton and planktivorous fishes. Since pelagic fish are more susceptible to hypoxic conditions than copepods, the spatial extent of the suitable habitat for fish was reduced during hypoxic events, while zooplankton may have found refuge from predation. Thus, hypoxic conditions reduced the predation risk of zooplankton by pelagic fish (Taylor and Rand, 2003).

Conversely, hypoxic conditions can also induce increased rates of predator-prey interaction (Kodama et al., 2006). Because some gelatinous species, such as the ctenophore Mnemiopsis leidyi, are more tolerant to low dissolved oxygen concentrations than their prey and competitors, hypoxia may have profound effects on trophic interactions (Decker et al., 2004). Under experimental conditions, clearance rates of zooplankton by large ctenophores were higher at low dissolved oxygen concentrations than under normoxic conditions. Ctenophore digestion rates seemed to be unaffected by hypoxic conditions of $0.7 \mathrm{~mL} \mathrm{O}_{2} \mathrm{~L}^{-1}$. In contrast, the jumping frequency of Acartia tonsa copepods decreased significantly with decreasing oxygen concentration (Decker et al., 2004). Such changes in prey behaviour under hypoxic conditions could affect encounter and capture rates, potentially making less-tolerant prey more vulnerable to predation in hypoxic waters. Since gelatinous species are more tolerant to hypoxia than fishes, they may be able to inhabit regions of low oxygen that are avoided by zooplanktivorous fishes with higher oxygen requirements. This could lead to a dominance of gelatinous predators in areas affected by severe hypoxia and might alter trophic pathways in these systems (Decker et al., 2004).

A change in the community structure will definitely have consequences for the remaining species in the ecosystem. Food organisms disappear, and new prey species may not be as suitable or as nutritious as the former ones. If other predator species occur, prey species may have to adapt to their different hunting behaviour. On the other hand, predatory pressure can be reduced in some cases such as the skipjack tuna that needs a minimum oxygen concentration of 3$3.5 \mathrm{~mL} \mathrm{O}_{2} \mathrm{~L}^{-1}$ (Barkley et al., 1978) to maintain consumption rates of $16.3 \mu \mathrm{mol} \mathrm{O}_{2} \mathrm{~g}^{-1} \mathrm{~h}^{-1}$ (Gooding et al., 1981). This high oxygen demand constrains the overlap of the predator species with potential prey (e.g. sardines and anchovies from eastern boundary upwelling areas). This argument was raised when discussing the increase of jumbo squid off California and Chile (Field, 2008; Vetter et al., 2008).

Yellowfin tuna seems to be less restricted in their vertical feeding migration by low DO concentrations. However, feeding dives deeper than $75 \mathrm{~m}$ (max. ca. $250 \mathrm{~m}$ ) are short and the fishes have to come back to the oxygenated surface waters for recovery (Schaefer et al., 2007). Swordfish is able to dive much deeper (ca. 500-600 m) and penetrate for several hours into the low oxygen layer where they find their food, mesopelagic fish. The large mass of white muscle in swordfish seems to enable the fish to accumulate oxygen debt in the muscles and the warm oxygenated surface water increases the recovery rate (Carey and Robison, 1981; Abscal et al., 2010). While skipjack and yellowfin tunas may suffer from increasing hypoxia, swordfish may withstand the changing environment, but it is unlikely that it can compensate the losses of biomass in the other species.

On the other hand, reduced oxygen can directly influence the food uptake of fish, as shown before. Shoji et al. (2005a) have reported on the reduced food uptake of juvenile Spanish mackerel Scomberomorus niphonius on red sea bream larvae with decreasing DO, while the consumption of fish larvae by moon jellyfish (Aurelia aurita) increased and hence contributed to a shift in the composition of the experimental community.

An increase in predation on fish larvae by jellyfish in oxygen-depleted waters was explained by a reduction in the larvae's ability to escape (Breitburg et al., 1994, 1997; Shoji et al., 2005a; Kodama et al., 2006). Decker et al. (2004) 
argued that the higher tolerance of ctenophores and other gelatinous plankton against hypoxic conditions allows them to outcompete young fish for staple food copepods, and leads to a dominance of gelatinous species and a change in the ecosystem's trophic structure and energy pathways. Such a shift to a jellyfish-dominated system may have happened in the Northern Benguela Current (Lynam et al., 2006).

Striped bass are influenced in their predatory behaviour at a DO of $2.8 \mathrm{~mL} \mathrm{O}_{2} \mathrm{~L}^{-1}$, and a level of at least $2.1 \mathrm{~mL} \mathrm{O}_{2} \mathrm{~L}^{-1}$ is required for the species to survive (Breitburg et al., 1994). In other species much lower thresholds were found. Naked gobies were reduced significantly in their feeding success or feeding attacks at DO of $0.5 \mathrm{~mL} \mathrm{O}_{2} \mathrm{~L}^{-1}$ (Breitburg et al., 1994). The authors concluded that low DO can strongly alter the absolute and relative importance of predators, especially on fish larvae in an estuary, but there is evidence that this argument can be generalised to other habitats and ecosystems.

Significant changes were also found in the diets of benthos feeders during and immediately after hypoxic events (Pihl, 1994; Pihl et al., 1992). These predators seemed to strongly benefit from the changing environment through increased access to larger prey items that were driven out of the anoxic sediments (Pihl et al., 1992). In contrast, sprat use the hypoxic deeper layers of a fjord in Norway to escape from its predators during the day (Kaartvedt et al., 2009). Neither whiting, nor cod enter these low oxygen layers with less than $20 \%$ oxygen saturation. Predation occurs mainly during the night when sprat move to the surface to feed on copepods. Similarly, moderate hypoxic conditions may serve as refuge from predation in freshwater fish communities (Hedges, 2007).

These findings indicate that the increasing hypoxic or even anoxic areas in the world ocean (Diaz and Rosenberg, 2008) and the expanding OMZ in the eastern parts of the subtropi$\mathrm{cal} /$ tropical oceans (Stramma et al., 2008) have a strong impact on the horizontal and vertical distribution of species and affect predator-prey-relationships. A driving force for this process is the time span and periodicity in which oxygen conditions vary. Mono-pulsed systems, where hypoxic events occur once a year, will react differently from multi-pulsed systems, such as upwelling areas. However, the effects of long-term climate-driven changes remain hard to predict.

Hypoxia tolerating shrimps of the Arabian Sea have an estimated average abundance of $0.04-106 / 1000 \mathrm{~m}^{3}$ and serve as important food resource for pelagic and mesopelagic organisms (Karuppasamy et al., 2006). An increase of their biomass and distribution area would be beneficial to their predators as well and would change the species composition in the upper trophic levels significantly.

We observe such a shift in the extending distribution area and biomass of the jumbo flying squid in the eastern Pacific Ocean (Gilly, 2005). Catches have increased from $15000 \mathrm{t}$ in 1990 to $818000 \mathrm{t}$ in 2006 (FAO, 2010a). Two factors may have contributed to the increased catches: the developing jumbo flying squid fisheries and the extension of the distribution area. In the early 1980s the distribution area for the species ranged from $\approx 30^{\circ} \mathrm{N}$ to $50^{\circ} \mathrm{S}$. In 2002 it was found up to $40^{\circ} \mathrm{N}$, in 2003 up to $50^{\circ} \mathrm{N}$ and in $2005 / 2006$ it occurred off the coast of Alaska at $60^{\circ} \mathrm{N}$ (Gilly, 2005). An important factor in this expansion could be temperature changes due to the ENSO phenomenon (Rodhouse, 2008) but Field (2008) also pointed out that this may not be the only factor responsible for the success of the squid at high latitudes. The extending OMZ is argued to be an additional factor responsible for the expansion of the squid habitat (Gilly et al., 2006). The increase in biomass of giant squid along the Californian shelf benefits predator species such as sharks (Vetter et al., 2008), but creates competition to other predatory species such as hake that itself falls into the role of prey (Field et al., 2007). Holmes et al. (2008) argue that the appearance of jumbo squid as top predator in areas formerly dominated by hake leads to a dispersal of hake to avoid predation by squid. A side effect may be that fishery effort on hake has to be increased in order to catch the same amount of fish. Interestingly, there is no such dominating squid species found in the Benguela upwelling system.

\section{Case studies}

Most of the ocean regions vulnerable to hypoxia, as listed by Diaz (2001), are estuaries, coastal areas and enclosed or semi-enclosed seas where water exchange is limited. Some of these regions, such as the Baltic Sea or Chesapeake Bay, have been intensively studied, and we know more or less the processes and consequences of oxygen depletion. With increasing research efforts in the open ocean and studies on the variability of upwelling systems, we realise that these open systems can also be vulnerable to short- and long-term changes of DO in the water column and on the sea floor. Semi-enclosed seas are of major concern as they are highly productive and thus important sources for food. At the same time, they are also heavily used for navigation and recreation. Their vulnerability originates from the disposal of waste, input of agricultural fertiliser and mining for minerals, sand and gravel (Snelgrove et al., 2009). Upwelling areas are affected by long-term changes in hydrography and especially in their oxygen distribution (Stramma et al., 2008; Oschlies et al., 2008).

We give one example each from a semi-enclosed sea and a coastal upwelling system in order to demonstrate the consequences of hypoxia to fish and other pelagic organisms in these ecosystems.

\subsection{Baltic Sea}

The Baltic Sea, certainly one of the most intensively studied seas in the world, is an almost completely enclosed sea (intracontinental mediterranean sea) connected to the North Sea only by two narrow straits, The Sound and Great Belt 


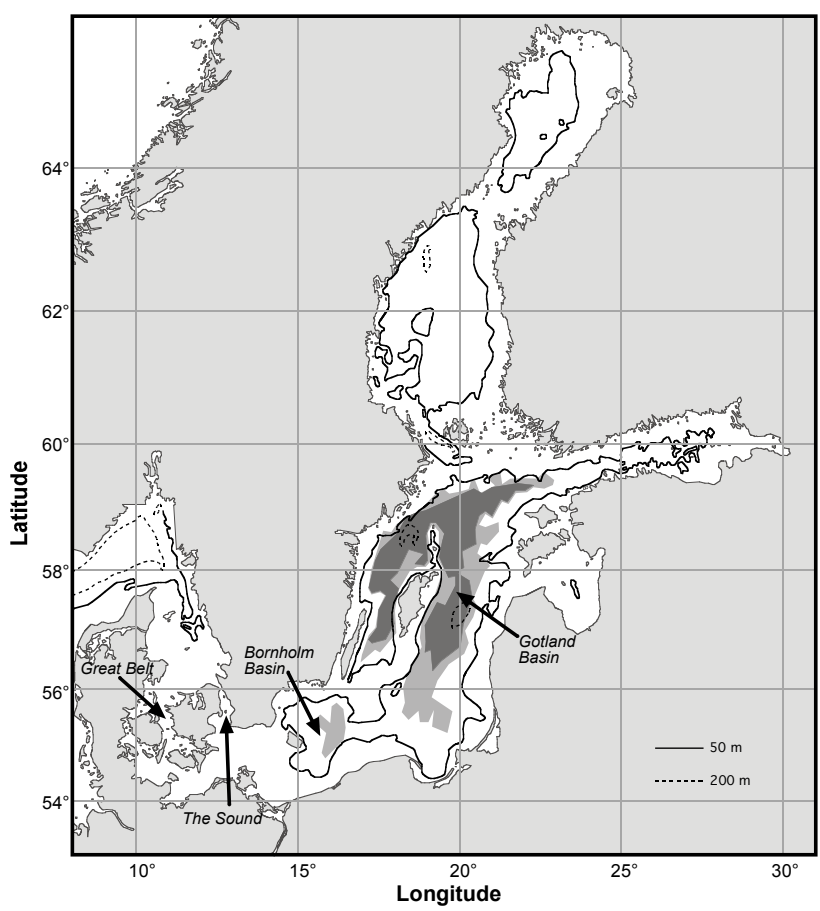

Fig. 4. Map of the Baltic Sea indicating the deep basins in the Baltic proper (Bornholm and Gotland basin). Given are the 50 and $200 \mathrm{~m}$ depth contours. The shaded areas represent oxygen deficiency $\left(<2 \mathrm{ml} \mathrm{O}_{2} \mathrm{~L}^{-1}\right)$ and anoxic $\left(\mathrm{H}_{2} \mathrm{~S}\right)$ conditions in August 2008. Dark grey areas indicate hydrogen sulphide distribution with maximum of ca. $5 \mathrm{ml} \mathrm{H}_{2} \mathrm{SL}^{-1}$. Source: http://www.io-warnemuende.de/ suboxische-und-anoxische-bereiche-im-tiefenwasser-der-ostsee. html (IOW, 2009).

(Fig. 4). The water body is strongly stratified with a sharp halocline at 70-90 m depth in the Baltic proper. The less saline surface layer originates from freshwater runoff in the large catchment basin while the more saline deeper layer results from occasional inflow events from the North Sea. Summarising reviews on the abiotic and biotic environment of the Baltic Sea include Rheinheimer (1995), Lozan et al. (1996), Jansson (2003), and Lääne et al. (2005). The strong stratification and an irregular inflow of well oxygenated North Sea water have lead to hypoxic and even anoxic conditions in the deeper basins. Matthäus (1995) has described this development for several basins in the Baltic Sea, showing low DO of $1-3 \mathrm{~mL} \mathrm{O}_{2} \mathrm{~L}^{-1}$ in the first half of the 20th century in the Gotland Deep and a steady decrease into $\mathrm{O}_{2}$ deficit $/ \mathrm{H}_{2} \mathrm{~S}$ occurrence in subsequent decades. This development is linked to the increased use of fertilisers for agriculture in the drainage basin countries, which has induced eutrophication in large parts of the Baltic Sea, which has resulted in oxygen deficiency in the less mixed deep waters (Fig. 5). The inflow of oxygenated waters from the North Sea has been less frequent since the mid 1970s (Matthäus, 1995), contributing to the decline of oxygen concentration

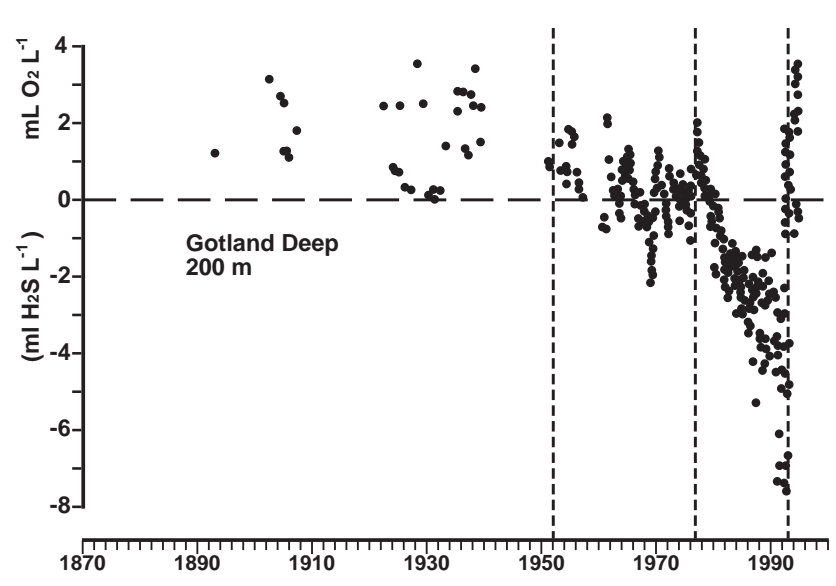

Fig. 5. Long-term variation in oxygen and hydrogen sulphide concentrations in the Gotland Deep water during the last century. Hydrogen sulphide is expressed as negative oxygen equivalents. (Extracted and redrawn from Matthäus, 1995.)

in the deeper waters. The effect is the reduction or elimination of benthic fauna in the deeper layers and high oxygen consumption by bacteria degrading the detritus. As a consequence, the new settlement of larvae of benthic organisms is prevented and re-colonisation is hindered. The area of sea floor affected by "dead zones" extended between 70000 and $100000 \mathrm{~km}^{2}$ in the $1970 \mathrm{~s}$, fluctuating on a yearly basis with maximum values at the end of stagnation periods (Rumohr, 1995). In 2008, $\mathrm{DO}<2 \mathrm{~mL} \mathrm{O}_{2} \mathrm{~L}^{-1}$ were found from $70 \mathrm{~m}$ downwards, filling the Gotland and Bornholm basins, and conditions were anoxic $\left(\mathrm{H}_{2} \mathrm{~S}\right)$ at depths below $150 \mathrm{~m}$ (IOW, 2009) (Fig. 4).

The stratification of the water column and the hypoxic/anoxic conditions in deeper water layers also affect pelagic species. The main commercially important fishes in the Baltic Sea are the pelagic herring (Clupea harengus), sprat (Sprattus sprattus) and the demersal cod (Gadus morhua) with catches >900000t in 1984 and 1997 (FAO, 2010a). Herring is a substrate spawner, laying its eggs in shallow, well-ventilated coastal places. Sprat and cod are pelagic spawners of the open sea above the deep basins. Sprat eggs spawned in the upper $20 \mathrm{~m}$ have high buoyancy and float near the surface above the thermocline. The eggs are sensitive to low temperatures and need at least $5{ }^{\circ} \mathrm{C}$ for normal development (Schnack, 1995). Sprat reproduction is thus more negatively impacted by long, cold winters than by low oxygen in deeper waters. By contrast, cod is better adapted to cold water temperatures and produces less buoyant eggs than sprat. The spawning areas of cod are more dependent on salinity than on temperature and coincide with the deep basins of the Baltic proper. A critical issue for the reproduction success of cod is the interaction between egg buoyancy, salinity and dissolved oxygen concentration. Spawning products of cod need a minimum salinity of $11 \mathrm{psu}$ for successful development. This is only found at greater 


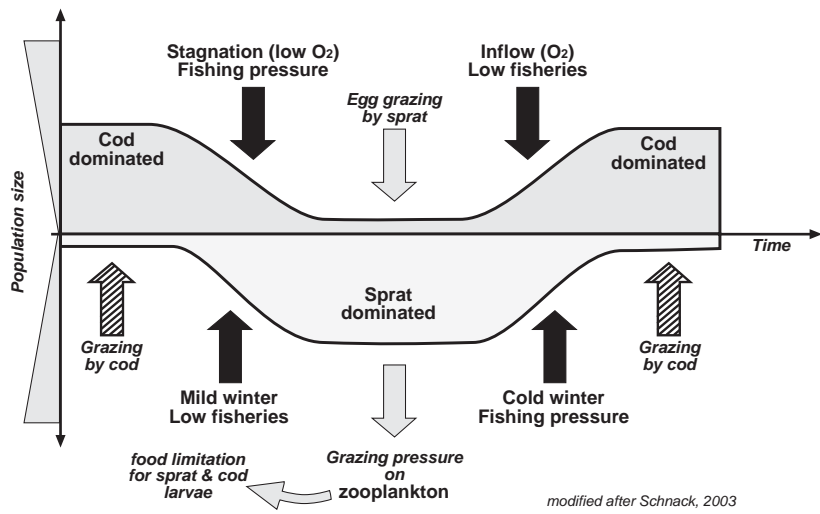

Fig. 6. Interrelationships between sprat and cod stocks, environmental factors, grazing, and fisheries in the Baltic Sea. The system shifts from being cod-dominated to sprat-dominated and back, as driven by environmental factors: North Sea water inflow - stagnation, cold winter - mild winter, biological drivers e.g. egg grazing by cod or sprat, zooplankton competition, and human activities such as cod and sprat fisheries (modified after Schnack, 2003).

depths around the thermocline. Egg concentrations occur at salinities between 9.5 and 16.5 psu (Nissling, 1994; Wieland, 1995) which are found at depths $>50-70 \mathrm{~m}$. Higher salinities stimulate better egg development and result in a need for the eggs to float as deep as possible and preferring the western basins, e.g. the Bornholm basin, rather than the more easterly basins (Nissling, 1994). At the same time, 1.7 to $2.1 \mathrm{~mL} \mathrm{O}_{2} \mathrm{~L}^{-1}$ is the oxygen threshold concentration below which the mortality of eggs increases significantly. However, oxygen concentrations at depths $>50-70 \mathrm{~m}$ depth can be in that range and thus become critical to the species. Hence, the spawning success of cod is strongly dependent on the inflows of North Sea water renewing and oxygenating the deep zones of the basins. Because of the different environmental requirements of sprat and cod, the changing conditions in the Baltic Sea induce a natural periodic fluctuation of the stocks driven predominantly by the periodicity and strength of the inflow of oxygenated North Sea water along the sea floor and the resulting vertical oscillations of the thermocline, halocline and oxycline.

Schnack (2003) and his co-workers have established a conceptual model to describe this fluctuating system and the variation in the biomass of the different components (Fig. 6): The model shows how the species react to the changing environment in the pelagic Baltic Sea. In a cod-dominated system, the sprat stock is kept at a low level by cool temperatures (bad development conditions for eggs) and predation by cod and carnivorous zooplankton. The system may shift into the sprat-dominated status when the cod stock is depressed by a combination of high fishing pressure and long stagnation phases without inflow of salty and oxygenated North Sea water. This stagnation lifts the oxycline upwards and cod eggs floating in the halocline are exposed to hypoxic conditions

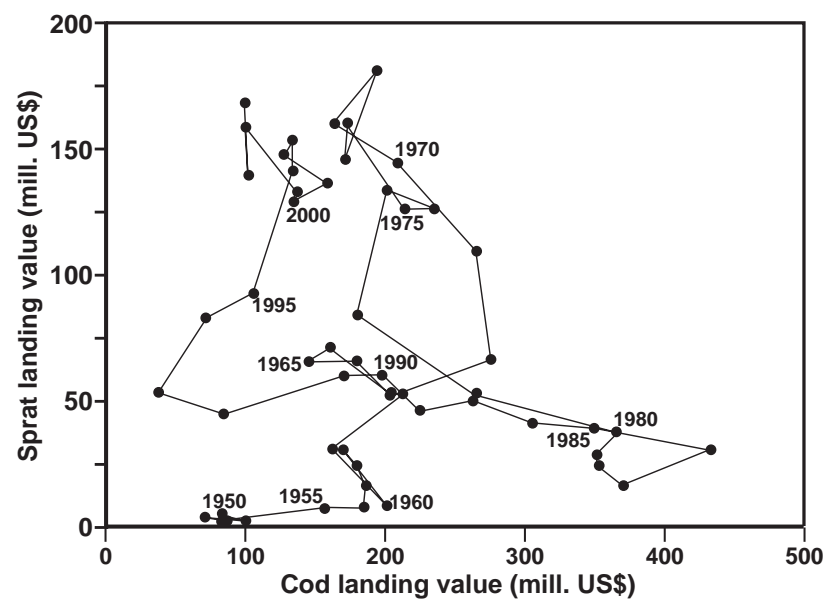

Fig. 7. Correlation between landing values of cod and sprat in the Baltic Sea from 1950 to 2004. Catches of sprat and cod substitute to a certain degree. Landing values of cod are rather stable for the period of 1955 to 1979. A short period of intensified fisheries ends in 1985 with a sharp decline in cod landing value to below the former revenue and remaining low until the present. The decline in landing value coincides with the lack of fresh North Sea water inflow. (Data from seaaroundus.org)

that reduce egg survival rates. Predation on sprat is reduced and mild winters enhance recruitment success of sprat. A sprat-dominated system causes increased predation on cod eggs. As long as the stagnation lasts, cod will have few chances to recover. A reverse change in the system may only occur if cold winters hinder sprat egg development and induce new inflow from the North Sea to oxygenate the deeper layers where cod eggs develop. Neuenfeldt and Beyer (2003) found a significant role of oxygen and salinity for the vertical distribution of cod and sprat and stated that reduced DO could not be compensated by seeking areas with lower temperature. Deep-water oxygen concentration and cod yearclass strength were clearly correlated during the period from 1958 to 1988 (Jansson, 2003). The expansion of oxygendeficient bottom water has caused strong shifts within the food web so that marine fishes (cod, sprat, herring) are impacted by both a loss in spawning area and a change of prey spectra in the Baltic Sea (Ojaveer and Kalejs, 2005).

Commercial fisheries follow these changes, but normally with a phase-delay of a few years to adapt fishing gear and method. The economic values of sprat and cod landings in the Baltic Sea are inversely correlated showing stable revenue between 200 and 300 million US\$ for cod from 1955, when fisheries had recovered after the war, to 1979 (Fig. 7). For this period a constant inflow of North Sea water (Matthäus, 1995) supported cod recruitment and fisheries in the area. A short period of elevated cod catches in the early eighties (perhaps as compensation for the reduced sprat catches) was followed by a dramatic decline in catch (ca. $100000 \mathrm{tyr}^{-1}$ ) and value (ca. 100 mill. US\$ yr${ }^{-1}$ ) and 
was accompanied by a period of minimum inflow (Matthäus, 1995). Revenue from cod catches remained at this low level from 1992 to 2004. Conversely, the sprat stock recovered since the early 1990s but cannot compensate the monetary loss in cod fishery (Fig. 7). The target of fisheries management in the Baltic Sea is to rebuild the cod stock and allow higher catches (Bastardie et al., 2010). While management has to consider both fisheries and environmental change, it can only influence fisheries. A simulation of the development of the Eastern Baltic cod stock has shown that in the long run, a further decrease of salinity (implying an increase in hypoxic areas) would bring the stock to a collapse even with a reduction in fishing effort (Röckmann et al., 2007). Only a significant reduction of fishing pressure and the implementation of a Marine Protected Area in the central Baltic Sea would elongate the time span for cod fisheries in the eastern Baltic Sea (Röckmann et al., 2009).

We have to accept that the environmental changes initiated by pollution, urbanisation and climate change will diminish some species in certain environments unless adaptive management practices consider environmental factors such as hypoxia. Semi-enclosed seas are more vulnerable to such processes than open seas where species may migrate away and find new habitats. In systems such as the Baltic Sea, Black Sea etc., marine species are land-locked and the only possibility for them to survive is adaptation, which requires time.

\subsection{Northern Benguela upwelling system}

The Benguela Current (BC) serves here as an example of an upwelling system. It stretches along the southwest African coast, roughly between about $14^{\circ} \mathrm{S}$ and $37^{\circ} \mathrm{S}$ (Fig. 8), and is one of the four major Eastern Boundary upwelling systems of the world's oceans. It encompasses the coastal upwelling regime, frontal jets and the eastern part of the South Atlantic gyre. The northern boundary is formed by the AngolaBenguela Front (ABF), which fluctuates north- and southward depending on the strength of the Benguela and Angola Currents and associated factors such as wind forcing between 14 and $17^{\circ} \mathrm{S}$ (Kostianoy and Lutjeharms, 1999).

The dynamics of the Benguela Current (BC) system have been described extensively (e.g. Shannon, 1985; Nelson and Hutchings, 1987; Lutjeharms and Valentine, 1987; Fennel, 1999; Mohrholz et al., 2001; Monteiro et al., 2008). There are several upwelling cells along the coast, the Lüderitz cell (at about $27^{\circ} \mathrm{S}$ ) is believed to be the most intense upwelling cell found in any of the world's upwelling systems, and effectively divides the system into a northern and a southern part (Duncombe Rae, 2005). Smaller upwelling cells are the Cunene cell off the Cunene River mouth, the Northern cell around Cape Frio, the Walvis Bay cell off Walvis Bay, and the Orange River cell off the mouth of the Orange River (Fig. 8).

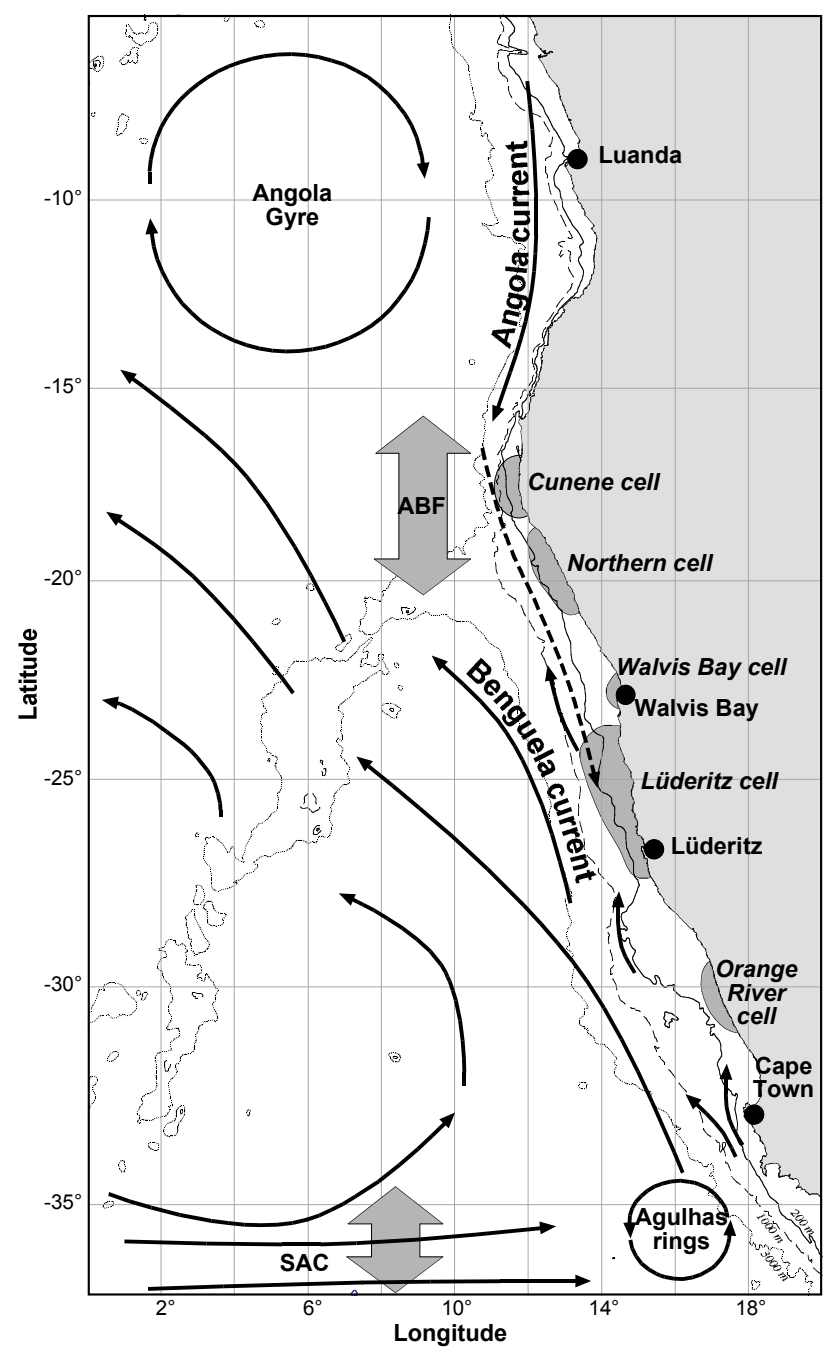

Fig. 8. The Benguela current upwelling area is stretching from $37^{\circ} \mathrm{S}$ to about $14^{\circ} \mathrm{S}$. The northern boundary is formed by the seasonally-migrating Angola-Benguela front (ABF). In the south the Benguela Current originates from the South Atlantic Current (SAC) and the Agulhas current flowing around the southern tip of Africa and reversing to the east in the Agulhas ring. Five major upwelling cells can be found along the coast in the Benguela current area, namely (from south to north) the Orange river cell at $30^{\circ} \mathrm{S}$, the Lüderitz cell (the strongest upwelling cell worldwide), the Walvis Bay cell, the Northern Namibian cell, and the Cunene cell. The Lüderitz upwelling cell divides the Benguela current ecosystem into a northern and a southern sub-system with different hydrographic regimes. The northern sub-system shows a pronounced OMZ modulated by a seasonally-varying poleward undercurrent and onshelf transport of South Atlantic Central Water.

The oxygen conditions in the water column are quite different in the two sub-systems, with a well developed Oxygen Minimum Zone in the northern part and well oxygenated waters in the southern part. OMZ are found in other upwelling areas as well (see Fig. 4 in Gilbert et al., 2009), but 


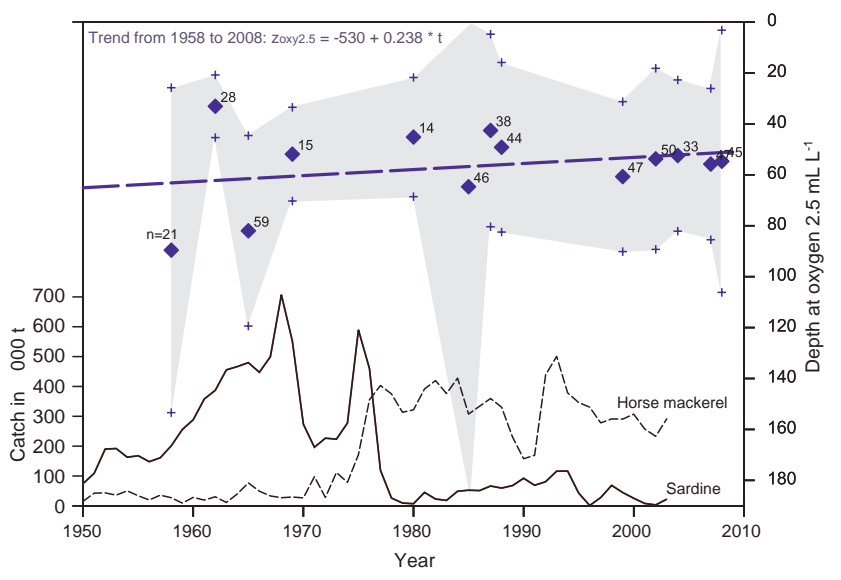

Fig. 9. Upper part: Development of the $\mathrm{O}_{2}=2.5 \mathrm{~mL} \mathrm{~L}^{-1}$ iso-surface in summer (January to March) from 1958 to 2008 off northern Namibia. Mean depth $(\diamond) \pm s$ (standard deviation, + , shaded area) of oxygen concentration $=2.5 \mathrm{~mL} \mathrm{O}_{2} \mathrm{~L}^{-1}$ was calculated for the area between $15^{\circ} \mathrm{S}$ and $24^{\circ} \mathrm{S}$, and between the coast and $1000 \mathrm{~m}$ water depth. $n$ is the number of stations used for calculating the mean in the respective year. The horizontal line indicates the trend in the overall mean depth of oxygen $=2.5 \mathrm{~mL} \mathrm{O}_{2} \mathrm{~L}^{-1}\left(z_{\text {oxy } 2.5}\right)$. The general trend can be described as a shoaling of the $2.5 \mathrm{~mL} \mathrm{O}_{2} \mathrm{~L}^{-1}$ iso-surface over the last 50 years (Data from National Oceanographic Data Center 2008; courtesy of Kreiner, NatMIRC and Ekau, 2007, 2008). Lower part: Development of sardine (solid line) and horse mackerel (dashed line) catches in metric tons during the last 50 years in the Namibian EEZ (Source: www.seaaroundus.org).

the special characteristic of the northern Benguela system is the southerly flowing Angola Current, which transports low oxygen water from the Angola Gyre polewards. In upwelling systems, the surplus of primary and secondary production that cannot be taken up by higher trophic levels, dies off and sinks to deeper layers where it is decomposed by oxygen demanding microbial processes. In oceanic waters, the OMZ $\left(<2 \mathrm{~mL} \mathrm{O}_{2} \mathrm{~L}^{-1}\right)$ extends from about 50 to $500 \mathrm{~m}$ depth and represents a chemical barrier for some vertically migrating species. The poleward transport of the hypoxic waters continues as an undercurrent along the slope reaching southward to Lüderitz $\left(27^{\circ} \mathrm{S}\right)$ and flowing partly on the shelf, influencing and decreasing the oxygen concentrations of the bottom water (Monteiro et al., 2008). In addition to the low oxygen pre-conditions in neritic waters, the sedimentation of organic material leads to strongly hypoxic or even anoxic conditions at the sea floor ("dead zones") and impacts the benthic fauna by selecting mostly low-oxygen resistant species in the benthos community (Zettler et al., 2009). Flushing of the shelf areas depends on the dynamics of the regional currents and water masses and occurs when the poleward undercurrent is at a minimum and the better oxygenated Cape Basin South Atlantic Central Water dominates the system (Monteiro et al., 2008).
Flushing and penetration of the shelf by hypoxic waters is an annually oscillating process with a maximum in oxygenated waters during September-November and a minimum during February-April (Hampton and Sweijd, 2008; Mohrholz et al., 2008; Monteiro et al., 2008). Extreme situations in late austral summer may lead to the production of $\mathrm{H}_{2} \mathrm{~S}$ in the bottom layers. $\mathrm{H}_{2} \mathrm{~S}$ and methane eruptions occur regularly and contribute to persistent water column hypoxia. Massive gas-charged sediments up to $480 \mathrm{~km}^{2}$ in extent were found by Emeis et al. (2004) in the near surface sediment layers along the coast of northern Namibia. Gas bubbles are strong enough to lift mud plaques up and release large amounts of gas into the water column. If this happens in the nearshore area, benthic animals can be driven ashore as has been observed in rock lobsters along the Namibian and South African coasts. Pelagic organisms may escape depending on the spatial extent of the affected area, but may also be trapped and washed ashore when they are encircled by hypoxic waters close to the shore.

The intensification of hypoxic conditions in the water column is an issue that emerged only recently, according to investigations in different upwelling systems (Bograd et al., 2008; Monteiro et al., 2008; Stramma et al., 2008). The data source for the Benguela system contains many gaps but shows a similar trend (Fig. 9). Pelagic organisms may suffer from hypoxia in a very different way than benthic organisms do, e.g. by impacting early ontogenetic development, feeding or predation. So far, only empirical data are available, which give evidence of a relationship between oxygen conditions in the water and abundance levels of species. Sardine stocks have been declining in the northern Benguela for several years and, with a few exceptions, yearly recruitment has been low (Fig. 9). At least in the case of the northern BC system, there is no evidence for the occurrence of "pseudocycles", as they were described for the Humboldt Current (Freon, 2008). It has been postulated that the sardine decline is related to the aggravated oxygen condition in the spawning areas on the Namibian shelf (Ekau and Verheye, 2005; Kreiner et al., 2009). Early stages of small pelagics are known to be sensitive to low oxygen (Palomera, 1991; Breitburg, 1994, 2002), so a key factor to explain decreasing stocks could lie in the early stages' inability to cope with low DO in the surface layer. Additional species in decline include horse mackerel (Trachurus spp.; Fig. 9) and to a certain extent hake (Merluccius spp.), which seem to be more resistant against hypoxia and recover much better than other organisms (Kunzmann and Buchholz, 2008).

An elevation of the upper oxycline of the OMZ over the last decades can be demonstrated for the northern Benguela Current from National Oceanographic Data Center bottle data (Fig. 9) coinciding with trends shown by Stramma et al. (2008) for all eastern tropical and subtropical oceans. This phenomenon has an impact on the reproduction success of pelagic species and predator-prey relationships. Similar trends have been observed in the California Current System, 
where anoxia in the water column is expanding (Chan et al., 2008) and the $60 \mu \mathrm{mol} \mathrm{O}_{2} \mathrm{~L}^{-1}\left(\approx 1.4 \mathrm{~mL} \mathrm{O}_{2} \mathrm{~L}^{-1}\right)$ oxycline has shifted upwards by 10 to $50 \mathrm{~m}$ at offshore stations, and up to $100 \mathrm{~m}$ at the inshore stations of the CalCOFI grid over the last 20 years (Bograd et al., 2008). Empirical studies on the distribution of fish larvae in northern Namibian waters showed clear evidence that higher abundances of many species are restricted to water masses with $>2.5 \mathrm{~mL} \mathrm{O}_{2} \mathrm{~L}^{-1}$ (Ekau and Verheye, 2005; Kreiner et al., 2009). Several species of copepods remain in the oxygenated surface layer, others enter the OMZ for resting/hiding from predators, and some perform vertical migrations through the OMZ during their life cycle (Auel et al., 2005; Auel and Verheye, 2007). Changes in the absolute oxygen concentration or in the vertical extent of the OMZ will directly influence plankton species in their activities and change the prey spectra of their predators.

Two long-term trends, consistent with global warming, have been discussed by Monteiro et al. (2008): a warming at the Angola-Benguela Front (ABF) and an increase in the lag between seasonal warming at Cape Frio and the following upwelling peak at the Lüderitz cell. It is argued that as a consequence of these two trends seasonal hypoxia will intensify with a long-term decline in the ecosystem function. The result will be a change in species composition of the pelagic realm. Several authors have explained the increase in jellyfish by changes in the environmental conditions, mainly temperature and oxygen, and human impacts such as fisheries or pollution (Purcell et al., 2007). Lynam et al. (2006) predict that jellyfish will out-compete finfish under increasingly hypoxic conditions. Jellyfish are usually more resistant to low oxygen concentrations (Table 2) and remain or congregate in such areas while fish rather avoid hypoxic areas. As they function as predators on zoo- and ichthyoplankton, an increase in jellyfish abundance will also increase predation pressure and competition on other zooplankton, which depresses the recovery chances of hypoxia-threatened plankton populations. The ability to remain in, or actively pass through, the OMZ could be a crucial advantage to survive and benefit from the large scale changes in the future. Mincks et al. (2000) reported of four shrimp species (Sergia spp.) that live nearly exclusively in the OMZ between $150-1000 \mathrm{~m}$ in the upwelling influenced areas off Oman in the Arabian Sea. The species fed on other shrimps, euphausiids and copepods from the same water depths and mostly remain in the OMZ. It is likely that these species have special physiological adaptations that allow them to live in this environment. An extension of the OMZ would provide them with an extended habitat and increase their abundance. A change in the overall community structure would then result from this.

Upwelling systems are of high economic importance representing a yearly landing value of 888 million US\$ in the Benguela Current (for comparison: 265 million US\$ in the California Current, 1539 million US\$ in the Canary Current and 5465 million US\$ in the Humboldt Current

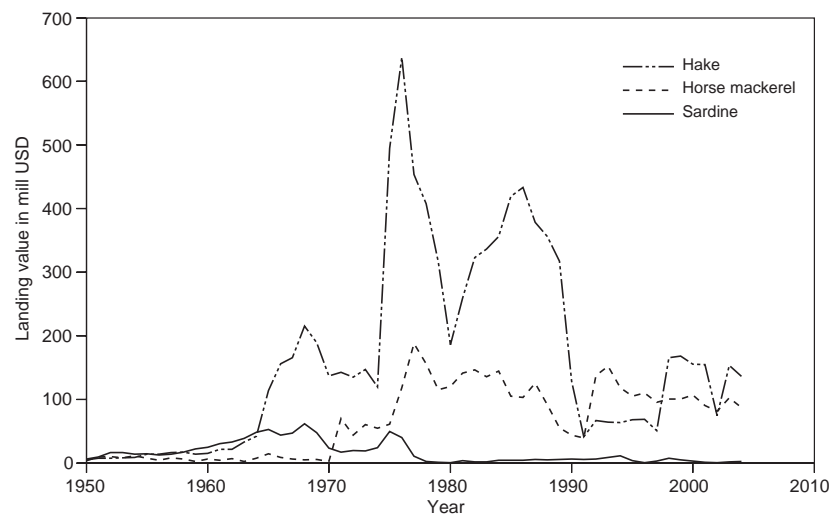

Fig. 10. Landing value of sardine (solid line), horse mackerel (dashed line) and hake (dashed and dotted line) in million US\$ during the last 50 years in the Namibian EEZ (Source: www. seaaroundus.org).

(seaaroundus.org, 2010; average for the period 1995-2004). The share for the northern Benguela system, which is coinciding more or less with the Namibian EEZ, is 298 million US\$. Target species for this revenue are hake and horse mackerel. Sardine was an important target species until the early 1970s, but its present value is close to nil (Fig. 10). About $90 \%$ of the total catch is exported to international markets. The value of export products was 375 million US\$ in 2005, nearly equal to all Namibian agriculture exports (FAO, 2010b). All three species show a negative trend in catch and landing value over the last years (Fig. 10). A large part of this decline may be due to heavy fishing in the area, but a coincidence with the decline of the oxygenated water layer in the area is also evident. If a further decline in the oxygen situation were to prevent the three stocks from recovering, the fisheries in the northern Benguela current may collapse completely even with a proper catch management (FAO, 2010b).

\section{Summary and conclusion}

Several studies have shown that degrading oxygen conditions are not restricted to semi-enclosed seas (e.g. Baltic Sea, Black Sea) or estuaries (e.g. Chesapeake Bay), but also occur in the open ocean. The underlying processes seem to happen on different time scales and periodicities compared to coastal or enclosed systems. Bograd et al. (2008) observed the shoaling of the upper boundary of the oxygen minimum layer in the California Current. The depth of the $1.4 \mathrm{~mL} \mathrm{O}_{2} \mathrm{~L}^{-1}$ $\left(60 \mu \mathrm{mol} \mathrm{O}_{2} \mathrm{~L}^{-1}\right)$ oxycline decreased $20-60 \mathrm{~m}$. Degradation may extend over decades as shown by Stramma et al. (2008) and driving forces are not pollution and eutrophication, but appear to be related to long-term climatic changes. Modelling the $\mathrm{P}_{\mathrm{CO}_{2}}$ development in the ocean over a period from the onset of the industrial revolution until 2100, Oschlies et 
al. (2008) found indications for a 50\% increase in the suboxic water volume by the end of this century.

The reaction of living communities in the affected areas is highly complex and far from fully understood. Effects occur on different levels of biological organisation: from individual level physiological responses due to changing temperature, oxygen and salinity (e.g. behaviour, growth or feeding), to changes in the population (e.g. recruitment, predation). The cumulative effect will be seen on community level where species composition and biomass distribution will change and percolate into fishery, tourism or other socio-economic stakeholder sectors. A forecast of specific impacts of the changing ecosystem on socio-economic sectors is difficult as species can be substituted by other species (see case studies). Dynamic end-to-end models that are driven by atmospheric data and can describe physical and biogeochemical processes in the ocean, do not include higher trophic levels above zooplankton (Fennel, 2009). The behaviour of fish or top predator populations is still too complex and plastic to give reliable results for single species in the models. Strong efforts are needed to widen the ecosystem model approaches and include top predators (including humans) that play a key role in the system. A prerequisite to succeed in such an approach is the knowledge of the physiological tolerance and constraints of the key species. Temperature and oxygen are central parameters in the response of organisms to changes in the environment which influence each other (Nilsson et al., 2009; Pörtner et al., 2009). pH and $\mathrm{P}_{\mathrm{CO}_{2}}$ are of increasing impact due to acidification of the ocean and its effect on the oxygen uptake of the organisms (Pörtner et al., 2004; Munday et al., 2009).

Possible scenarios for climate induced changes in the pelagic zone (Bindoff et al., 2007; Meehl et al., 2007; Stramma et al., 2008) include:

- Vertical extension of the OMZ combined with a decrease of DO in the centre of the OMZ

\section{- Horizontal extension of OMZ}

- Increased water temperature

- Acidification with increased $\mathrm{P}_{\mathrm{CO}_{2}}$

From our knowledge on the physiological processes and empirical observations, we know that there will be winners and losers in the changing ecosystems. Increasing hypoxia seems to benefit gelatinous plankton and/or squid as observed in the Benguela and California current regions. Other components of the "classical" marine foodweb are negatively affected: certain copepods and fish. Within these groups the response is very complex. In general, small pelagic fish species, such as clupeids, could be more vulnerable than higher evolved and more adaptable species such as gobies or flat fish. No systematic investigation exists on whether higher evolved fishes are more tolerant or adaptive to hypoxic conditions than less evolved ones. We know from young sea bass, that this species is able to adapt the respiratory surface of its gills depending on different DO conditions over a period of three months (Saroglia et al., 2002), but we cannot say if this is a general feature in fish.

Tunas and sharks are forced to permanent swimming to cover their high oxygen demand. In a changing environment they will likely be one of the first species to leave. Prince and Goodyear (2006) found evidence that shoaling of the OMZ is significantly reducing the habitat of Atlantic blue and white marlin and sailfish. Even the jumbo squid, which seems to benefit from the horizontal extension of the OMZ through competitive advantages over other top predators, could suffer from a vertical extension of the OMZ (Rosa and Seibel, 2008).

The winners of the intra-specific competition under low oxygen conditions seem to be smaller specimens that outcompete larger ones due to their advantageous body-massoxygen-consumption ratios (Burleson et al., 2001). As larger specimens will likely be the ones to first retreat from unfavourable oxygen conditions, there will be an impact on the age composition of the stocks, which may change recruitment abilities as well as predation pressure on food organisms. Hence, trophic interactions will change and carbon fluxes will follow different pathways. Different species or even entire taxonomic groups will use the free resources and increase their stock sizes. We may observe similar effects as described in the "Fishing down the food web" concept by Pauly et al. (1998) through a lowering of the overall trophic level in the system and an increased importance of smallsized species and specimens. Not all of these "new" species, e.g. jellyfish, will be usable for mankind.

To achieve a deeper understanding of the processes and forecast the consequences of the induced changes, we need a better understanding of the physiological adaptation mechanisms and potentials on the species level. The scope for adaptation and behavioural response of the species to these changes is set by their very basic physiological characteristics. Here are the key factors that guarantee the survival of the species under changing conditions or lead to extinction. We know some of the mechanisms that play a key role in these processes and some principle differences between taxonomic groups or modes of life, but we are far from having these parameters on hand for the key species in the ecosystems to incorporate them in our models. Strong efforts have to be made to investigate the physiological and behavioural response of species to combined changes in parameters such as temperature, oxygen, $\mathrm{pH}$ and $\mathrm{P}_{\mathrm{CO}_{2}}$. Empirical correlations have to be verified and validated by experimental results and models. Physiological studies on the response of organisms to temperature and oxygen are mostly performed on benthic, estuarine or freshwater species to analyse basic processes. Open water pelagic species differ in their tolerance levels and thus the range of their acceptable "environmental window". 
The economic consequences of hypoxia on pelagic resources are difficult to estimate and examples are scarce. Every square $\mathrm{km}$ of additional hypoxic area in the Gulf of Mexico reduces brown shrimp catch by $214 \mathrm{~kg}$ (O'Connor and Whittall, 2007). Standard fish catches in the Danish North Sea, after the intrusion of hypoxic waters, dropped from 700$900 \mathrm{~kg} \mathrm{~h}^{-1}$ to nearly nil (Detlefsen and Westernhagen, 1983). The decline of the small pelagics in the Northern Benguela Upwelling system may partly be related to the shoaling of the OMZ, which has resulted in an almost complete disappearance of the sardine fishery in Namibia. Remaining predator species, such as horse mackerel or hake, seem to have switched to a diet of mesopelagic fish and other organisms. It is unclear if this really compensates the loss of their former staple food. Catches and landing value of hake and horse mackerel are declining (Figs. 9 and 10). The OMZ has also become shallower in the eastern tropical Pacific (Prince and Goodyear, 2006), and there is evidence that it has decreased the vertical range of tuna and made them more vulnerable to purse seiner and pole and line fisheries (Green, 1967; Barkeley et al., 1978) with an overall increase of the catch. This could be positive in the short-term, but could also make them more vulnerable to overfishing. The increase in jumbo squid biomass and distribution with a fourfold catch increase between 2000 and 2005 may also be an example for a positive economic side-effect (Field, 2008). However, competing species such as hake may decline in biomass and cause economical losses (Holmes et al., 2008).

In 2007, the US commercial fisheries had a primary sales value of 5.1 billion US\$. After processing, wholesale and retail activities the value was 68 billion US\$ (Cooley and Doney, 2009). Based on models, the authors predicted economical losses from catch declines due to acidification for the sector of mollusc fisheries to reach 87-189 million US\$. And we know from the demersal brown shrimp (Farfantepenaeus aztecus) fisheries in the northern Gulf of Mexico, that the spatial extent of hypoxic areas is significantly negatively correlated with the fisheries' landings from 1985 to 2004 (Zimmerman and Nance, 2001; Craig et al., 2005; O'Connor and Whitall, 2007). These numbers may give an idea of the potential economic losses that hypoxia may create.

The shift in temperature distribution predicted by IPCC (Bindoff et al., 2007) will lead to a redistribution of fish stocks and fisheries catch potentials (Cheung et al., 2010). Disadvantaged areas are the low latitudes while high latitudes are likely to benefit. Low latitudes also encompass the main distribution of the OMZ and their extension will worsen the impact of temperature changes as outlined in Sect. 2.

So far we have only mentioned the directly measurable effects in fisheries caused by ecosystem changes through hypoxia. A healthy ecosystem does not only provide mankind with production services, i.e. food and raw material, but to a larger extent with regulation, cultural and supporting services (Beaumont et al., 2008). The decrease in biodiversity in hypoxic areas will reduce ecosystem resilience and resistance and may decrease its function in nutrient cycling processes. Fishes seem to play an important role in global carbon cycle in balancing the production and dissolution processes of carbonate (Jennings and Wilson, 2009). The decline of fish stocks due to an extending hypoxia could enhance $\mathrm{P}_{\mathrm{CO}_{2}}$ in the upper water layers and thus make organisms more vulnerable to hypoxia, resulting in a self-sustaining negative loop.

Acknowledgements. We thank SCOR for supporting the Working Group 128 on Coastal Hypoxia and stimulating this review. We also thank all members of the SCOR Working Group for their fruitful discussions since the beginning. We thank W. Matthäus and W. Fennel from Institute for Baltic Sea Research (IOW) and D. Schnack from IfM-Geomar, Kiel, for providing Figs. 3, 4 and 5. Figure 7 is based on data collected during several cruises in the Benguela region stored in the data base of the National Museum Information and Research Center (NatMIRC) in Swakopmund, Namibia. Our thanks go to Anja Kreiner and Anja van der Plas who made the data available for us.

Edited by: J. Zhang

\section{References}

Abascal, F. J., Mejuto, J., Quintans, M., and Ramos-Cartelle, A.: Horizontal and vertical movements of swordfish in the Southeast Pacific, Ices J. Mar. Sci., 67, 466-474, 2010.

Alderdice, D. F. and Forrester, G. R.: Some effects of salinity and temperature on early development and survival of the English sole (Parophrys vetulus), J. Fish. Res. Board Can., 25, 495-521, 1968.

Angiletta, M.: Thermal adaptation, A theoretical and empirical analysis, Oxford University Press, New York, 289 pp., 2009.

Arguélles, J., Tafur, R., Taipe, A., Villegas, P., Keyl, F., Dominguez, N., and Salazar, M.: Size increment of jumbo flying squid Dosidicus gigas mature females in Peruvian waters, 1989-2004, Prog. Oceanogr., 79, 308-312, doi:10.1016/j.pocean.2008.10.003, 2008.

Attrill, M. J., Wright, J., and Edwards, M.: Climate-related increases in jellyfish frequency suggest a more gelatinous future for the North Sea, Limnol. Oceanogr., 52(1), 480-485, 2007.

Auel, H., Hagen, W., Ekau, W., and Verheye, H. M.: Metabolic adaptations and reduced respiration of the copepod Calanoides carinatus during diapause at depth in the Angola-Benguela Front and northern Benguela upwelling regions, Afr. J. Mar. Sci., 27, 653-657, 2005.

Auel, H. and Verheye, H. M.: Hypoxia tolerance in the copepod Calanoides carinatus and the effect of an intermediate oxygen minimum layer on copepod vertical distribution in the northern Benguela Current upwelling system and the Angola-Benguela Front, J. Exp. Mar. Biol. Ecol., 352, 234-243, 2007.

Auel, H. und Ekau, W.: Distribution and respiration of the highlatitude pelagic amphipod Themisto gaudichaudi in the Benguela Current in relation to upwelling intensity, Prog. Oceanogr., 83, 237-241, 2009.

Barkley, R. A., Neill, W. H., and Gooding, R. M.: Skipjack tuna, Katsuwonus pelamis, habitat based on temperature and oxygen requirements, Fish. B. NOAA, 76(3), 653-662, 1978. 
Bastardie, F., Vinther, M., Nielsen, J. R., Ulrich, C., and Paulsen, M. S.: Stock-based vs. fleet-based evaluation of the multi-annual management plan for the cod stocks in the Baltic Sea, Fish. Res., 101 (3), 188-202, 2010.

Beaumont, N. J., Austen, M. C., Mangi, S. C., and Townsend, M.: Economic valuation for the conservation of marine biodiversity, Mar. Pollut. Bull., 56(3), 386-396, 2008.

Behrens, J. and Steffensen, J. F.: The effect of hypoxia on behavioural and physiological aspects of lesser sandeel, Ammodytes tobianus (Linnaeus, 1785), Mar. Biol., 150, 1365-1377, 2007.

Bejda, A. J., Studholme, A. L., and Olla, B.: Behavioral responses of red hake, Urophycis chuss, to decreasing concentrations of dissolved oxygen, Environ. Biol. Fish., 19(4), 261-268, 1987.

Bejda, A. J., Phelan, B. A., and Studholme, A. L.: The effect of dissolved-oxygen on the growth of Young-of-the-year winter flounder, Pseudopleuronectes americanus, Environ. Biol. Fish., 34(3), 321-327, 1992.

Berschick, P., Bridges, C. R., and Grieshaber, M. K.: The influence of hyperoxia, hypoxia and temperature on the respiratory physiology of the intertidal rockpool fish Gobius cobitis Pallas, J. Exp. Biol., 130, 369-387, 1987.

Bindoff, N. L., Willebrand, J., Artale, V., Cazenave, A., Gregory, J., Gulev, S., Hanawa, K., Le Quéré, C., Levitus, S., Nojiri, Y., Shum, C. K., Talley, L. D., and Unnikrishnan, A.: Observations: Oceanic Climate Change and Sea Level, in: Climate Change 2007: The Physical Science Basis, Contribution of Working Group I to the Fourth Assessment Report of the Intergovernmental Panel on Climate Change, edited by: Solomon, S., Qin, D., Manning, M., Chen, Z., Marquis, M., Averyt, K. B., Tignor, M., and Miller, H. L., Cambridge University Press, Cambridge, UK and New York, NY, USA, 2007.

Boeuf, G., Boujard, D. and Person-Le Ruyet, J.: Control of the somatic growth in turbot, J. Fish. Biol., 55, 128-147, 1999.

Bograd, S., Castro, C., Di Lorenzo, E., Palacios, D., Bailey, H., Gilly, W. F., and Chavez, F.: Oxygen declines and the shoaling of the hypoxic boundary in the California Current, Geophys. Res. Lett., 35, 1-6, doi:10.1029/2008GL034185, 2008.

Böttger-Schnack, R.: Vertical structure of small metazoan plankton, especially noncalanoid copepods, I. Deep Arabian Sea, J. Plankton Res., 18, 1073-1101, 1996.

Braum, E.: Einflüsse chronischen exogenen Sauerstoffmangels auf die Embryogenese des Herings (Clupea harengus), Neth. J. Sea Res., 7, 363-375, 1973.

Braun, N., de Lima, R. L., Moraes, B., Loro, V. L., and Baldisserotto, B.: Survival, growth and biochemical parameters of silver catfish, Rhamdia quelen (Quoy and Gaimard, 1824), juveniles exposed to different dissolved oxygen levels, Aquac. Res., 37, 1524-1531, 2006.

Breitburg, D. L.: Behavioral response of fish larvae to low dissolved oxygen concentrations in a stratified water column, Mar. Biol., 120, 615-625, 1994.

Breitburg, D. L., Steinberg, N., Du Beau, S., Cooksey, C., and Houde, E. D.: Effects of low dissolved oxygen on predation on estuarine fish larvae, Mar. Ecol.-Prog. Ser., 104, 235-246, 1994.

Breitburg, D. L., Loher, T., Pacey, C., and Gerstein, A.: Varying effects of low dissolved oxygen on trophic interactions in an estuarine food web, Ecol. Monogr., 67, 489-507, 1997.
Breitburg, D. L.: Effects of hypoxia, and the balance between hypoxia and enrichment, on coastal fishes and fisheries, Estuaries, 25(4), 767-781, 2002.

Brett, J. R., Groves, T. D. D., and Hoar, R.: Physiological energetics, in: Fish Physiology, Vol. VIII, edited by: Randall, D. J. and Brett, J. R., 279-352, 1979.

Brett, J. R. and Blackburn, J. M.: Oxygen requirements for growth of young coho (Onchorhynchus kisutch) and sockeye (Onchorhynchus nerka) salmon at degrees C, Can. J. Fish. Aquat. Sci., 38(4), 399-404, 1981.

Buchner, T., Abele, D., and Pörtner, H. O.: Oxyconformity in the intertidal worm Sipunculus nudus: the mitochondrial background and energetic consequences, Comp. Biochem. Phys. B, 109-120, 2001.

Burleson, M., Wilhelm, D., and Smatresk, N.: The influence of fish size on the avoidance of hypoxia and oxygen selection by largemouth bass, J. Fish. Biol., 59, 1336-1349, 2001.

Bushnell, P.G. and Brill, R.W.: Responses of swimming skipjack (Katsuwonus pelamis) and yellowfin (Thunnus albacares) tunas to acute hypoxity, and a model of their cardiorespiratory function, Physiol. Zool., 64(3), 787-811, 1991.

Carey, F. G. and Robison, B. H.: Daily patterns in the activitites of swordfish, Xiphias gladius, observed by acoustic telemetry, Fish. B.-NOAA, 79(2), 277-292, 1981.

Carlson, A. R., Blocher, J., and Herman, L. J.: Growth and survival of channel catfish and yellow perch exposed to lowered constant and diurnally fluctuating dissolved-oxygen concentrations, Prog. Fish Cult., 42(2), 73-78, 1980.

Castro, L. R., Bernal, P. A., and Troncoso, V. A.: Coastal intrusion of copepods: mechanisms and consequences on the population biology of Rhincalanus nasutus, J. Plankton Res., 15(5), 501515, 1993.

Chabot, D. and Dutil, J. D.: Reduced growth of Atlantic cod in nonlethal hypoxic conditions, J. Fish. Biol., 55(3), 472-491, 1999.

Chabot, D. and Claireaux, G.: Environmental hypoxia as a metabolic constraint on fish: the case of Atlantic cod, Gadus morhua, Mar. Pollut. Bull., 57, 287-294, 2008.

Chan, F., Barth, J. A., Lubchenco, J., Kirincich, A., Weeks, H., Peterson, W. T., and Menge, B.: Emergence of anoxia in the California current large marine ecosystem, Science, 920, 2008.

Chapman, L. J., Chapman, C. A., Nordlie, F. G., and Rosenberger, A. E.: Physiological refugia: swamps, hypoxia tolerance and maintenance of fish diversity in the Lake Victoria region, Comp. Biochem. Phys. A, A133, 421-437, 2002.

Cheung, W. W. L., Lam, V. W. Y., Sarmiento, J. L., Kearney, K., Watson, R., Zeller, D., and Pauly, D.: Large-scale redistribution of maximum fisheries catch potential in the global ocean under climate change, Global Change Biol., 16(1), 24-35, 2010.

Childress, J. J. and Seibel, B. A.: Life at stable low oxygen levels: Adaptations of animals to oceanic oxygen minimum layers, J. Exp. Biol., 201(8), 1223-1232, 1998.

Ciuhandu, C. S., Wright, P. J., Goldberg, J. I., and Stevens, E. D.: Parameters influencing the dissolved oxygen in the boundary layer of rainbow trout (Oncorhynchus mykiss) embryos and larvae, J. Exp. Biol., 210, 1435-1445, 2007.

Cooley, S. R. and Doney, S. C.: Anticipating ocean acidification's economic consequences for commercial fisheries, Environ. Res. Lett., 4(2), 024007, doi:10.1088/1748-9326/4/2/024007, 2009. 
Craig, J. K., Crowder, L. B., and Henwood, T. A.: Spatial distribution of brown shrimp (Farfantepenaeus aztecus) on the northwestern Gulf of Mexico shelf: effects of abundance and hypoxia, Can. J. Fish. Aquat. Sci., 62(6), 1295-1308, 2005.

Crampton, W. G. R.: Effects of anoxia on the distribution, respiratory strategies and electric signal diversity of gymnotiform fishes, J. Fish. Biol., 53, 307-330, 1998.

Crocker, C. E. and Cech, J. J.: Effects of environmental hypoxia on oxygen consumption rate and swimming activity in juvenile white sturgeon, Acipenser transmontanus, in relation to temperature and life intervals, Environ. Biol. Fish., 50, 383-389, 1997.

Czerkies, P., Brzuzan, P., Kordalski, K., and Luczynski, M.: Critical partial pressures of oxygen causing precocious hatching in Coregonus lavaretus and C. albula embryos, Aquaculture, 196, 151-158, 2001.

D'Amours, D.: The distribution of cod (Gadus morhua) in relation to temperature and oxygen level in the Gulf of St. Lawrence, Fish. Oceanogr., 2, 24-29, 1993.

DallaVia, J., Thillart, G. V. D., Cattani, O., and Cortesi, P.: Behavioural responses and biochemical correlates in Solea solea to gradual hypoxic exposure, Can. J. Zool., 76, 2108-2113, 1998.

Das, T. and Stickle, W. B.: Sensitivity of crabs Callinectes sapidus and $C$. similis and the gastropod Stramonita haemastoma to hypoxia and anoxia, Mar. Ecol.-Prog. Ser., 98(3), 263-274, 1993.

Das, T. and Stickle, W. B.: Detection and avoidance of hypoxic water by juvenile Callinectes sapidus and C. similis, Mar. Biol., 120(4), 593-600, 1994.

De Boeck, G., Vlaeminck, A., Van der Linden, A., and Blust, R.: Salt stress and resistance to hypoxic challenges in the common carp (Cyprinus carpio L.), J. Fish. Biol., 57, 761-776, doi:10.1006/jfbi.2000.1349, 2000.

De Silva, C. and Tytler, P.: The influence of reduced environmental oxygen on the metabolism and survival of herring and plaice larvae, Neth. J. Sea Res., 7, 345-362, 1973.

Decker, M. B., Breitburg, D. L., and Purcell, J. E.: Effects of low dissolved oxygen on zooplankton predation by the ctenophore Mnemiopsis leidyi, Mar. Ecol.-Prog. Ser., 280, 163172, doi:10.3354/meps280163, 2004.

Demers, A., Souty-Grosset, C., Trouilhé, M., Füreder, L., Renai, B., and Gherardi, F.: Tolerance of three European native species of crayfish to hypoxia, Hydrobiologia, 560, 425-432, 2006.

Depêche, J. and Billard, R.: Embryology in fish - A review, Societé Française d'Ichthyologie, 123 pp., 1994.

Dethlefsen, V. and Westernhagen, H. V.: Oxygen deficiency and effects on bottom fauna in the eastern German Bight 1982, Meeresforschung, 30, 42-53, 1983.

Diaz, R. J.: Overview of hypoxia around the world, J. Environ. Qual., 30, 275-281, 2001.

Diaz, R. J. and Rosenberg, R.: Spreading dead zones and consequences for marine ecosystems, Science, 321, 926-929, doi:10.1126/science.1156401, 2008.

Dizon, E.: Effect of dissolved oxygen concentration and salinity on swimming speed of two species of tunas, Fish. Bull., 75(3), 649-653, 1977.

Domenici, P., Steffensen, J. F., and Batty, R. S.: The effect of progressive hypoxia on swimming activity and schooling in Atlantic herring, J. Fish. Biol., 57, 1526-1538, 2000.
Domenici, P.: The effect of progressive hypoxia on school structure and dynamics in Atlantic herring Clupea harengus, P. Roy. Soc. B-Biol. Sci., 269, 2103-2111, 2002.

Duncombe Rae, C. M.: A demonstration of the hydrographic partition of the Benguela upwelling ecosystem at 26 degrees $40^{\prime} \mathrm{S}$, Afr. J. Mar. Sci., 27, 617-628, 2005.

Dutil, J.-D., Sylvestre, E.-L., Gamache, L., Larocque, R., and Guderley, H.: Burst and coast use, swimming performance and metabolism of Atlantic cod Gadus morhua in sub-lethal hypoxic conditions, J. Fish Biol., 71(2), 363-375, 2007.

Ekau, W. and Verheye, H. M.: Influence of oceanographic fronts and low oxygen on the distribution of ichthyoplankton in the Benguela and southern Angola currents, Afr. J. Mar. Sci., 27, 629-639, 2005.

Ekau, W. and Bröhl, S.: Changes in fish larval community of the northern Benguela upwelling over the last decade induced by changes in the oxygen minimum layer? Eastern boundary upwelling ecosystems, integrative and comparative approaches, 26 June 2008, Las Palmas, Gran Canaria, Spain, 172, 2008.

Emeis, K. C., Brüchert, V., Currie, B., Endler, R., Ferdelman, T., Kiessling, A., Leipe, T., Noli-Peard, K., Struck, U., and Vogt, T.: Shallow gas in shelf sediments of the Namibian coastal upwelling ecosystem, Cont. Shelf Res., 24, 627-642, 2004.

Escribano, R.: Zooplankton interactions with the oxygen minimum zone in the eastern south pacific, Gayana (Concepc.), 70,(supl. 1), 19-21, 2006.

Escribano, R., Hidalgo, P., and Krautz, C.: Zooplankton associated with the oxygen minimum zone system in the northern upwelling region of Chile during March 2000, Deep-Sea Res. Pt. II, 56, 1049-1060, doi:10.1016/j.dsr2.2008.09.009, 2009.

FAO: Fisheries statistics and information, http://www.fao.org/fi/, last access: April 2010, 2010a.

FAO: Country report Namibia, http://www.fao.org/fishery/ countrysector/FI-CP_NA/en, last access: April 2010, 2010b.

Fennel, W.: Theory of the Benguela upwelling system, J. Phys. Oceanogr., 29(2), 177-190, 1999.

Fennel, W.: Parameterizations of truncated food web models from the perspective of an end-to-end model approach, J. Mar. Syst., 76(1-2), 171-185, 2009.

Field, J. C., Baltz, K., Phillips, A. J., and Walker, W. A.: Range expansion and trophic interactions of the jumbo squid, Dosidicus Gigas, in the California Current, CalCOFI Rep., 48, 131-146, 2007.

Field, J. G.: Jumbo squid (Dosidicus gigas) invasions in the eastern Pacific Ocean, CalCOFI Rep., 49, 79-81, 2008.

Finenko, G. A., Kideys, A. E., Anninsky, B. E., Shiganova, T. A., Roohi, A., Tabari, M. R., Rostami, H., and Bagheri, S.: Invasive ctenophore Mnemiopsis leidyi in the Caspian Sea: feeding, respiration, reproduction and predatory impact on the zooplankton community, Mar. Ecol.-Prog. Ser., 314, 171-185, 2006.

Fischer, P., Rademacher, K., and Kils, U.: In situ investigations on the respiration and behaviour of the eelpout Zoarces viviparus under short-term hypoxia, Mar. Ecol.-Prog. Ser., 88, 181-184, 1992.

Freon, P., Bouchon, M., Mullon, C., Garcia, C., and Niquen, M.: Interdecadal variability of anchoveta abundance and overcapacity of the fishery in Peru, Prog. Oceanogr., 79(2-4), 401-412, 2008. 
Gilbert, D., Rabalais, N. N., Diaz, R. J., and Zhang, J.: Evidence for greater oxygen decline rates in the coastal ocean than in the open ocean, Biogeosciences Discuss., 6, 9127-9160, doi:10.5194/bgd-6-9127-2009, 2009.

Gilly, W. F.: Spreading and stranding of Humboldt squid, Ecosystem observations for the Monterey Bay National Marine Sanctuary, Monterey Bay Natl. Mar. Sanctuary report, Monterey, Calif., 20-22, 2005.

Gilly, W. F., Markaida, U., Baxter, C., Block, B., Boustany, A., Zeidberg, L., Reisenbichler, K., Robison, B., Bazzino, G., and Salinas Zavala, C.: Vertical and horizontal migrations by the jumbo squid Dosidicus gigas revealed by electronic tagging, Mar. Ecol.Prog. Ser., 324, 1-17, 2006.

Gonzales, R. R. and Quiñones, R. A.: Ldh activity in Euphausia mucronata and Calanus chilensis: implications for vertical migration behaviour, J. Plankton Res., 24, 1349-1356, 2002.

Gooding, R. M., Neill, W. H., and Dizon, A. E.: Respiration rates and low-oxygen tolerance limits in skipjack tuna, Katsuwonus pelamis, Fish. B-NOAA, 79(1), 31-48, 1981.

Gorr, T. A., Rider, C. V., Wang, H. Y., Olmstead, A. W., and LeBlanc, G. A.: A candidate juvenoid hormone receptor ciselement in the Daphnia magna hb2 hemoglobin gene promoter, Mol. Cell Endocrinol., 247, 91-102, 2006.

Graham, W. M.: Numerical increases and distributional shifts of Chrysaora quinquecirrha (Desor) and Aurelia aurita (Linne) (Cnidaria : Scyphozoa) in the northern Gulf of Mexico, Hydrobiologia, 451, 97-111, 2001.

Grashoff, K., Ehrhardt, M., and Kremling, K.: Methods of seawater analysis, Verlag Chemie, Basel, 2nd edition, 419 pp., 1983.

Gray, C. and Kingsford, M. J.: Variability in thermocline depth and strength, and relationships with vertical distributions of fish larvae and mesozooplankton in dynamic coastal waters, Mar. Ecol.Prog. Ser., 247, 211-224, 2003.

Green, R. E.: Relationship of the thermocline to success of purse seining for tuna, Trans. Am. Fish. Soc., 96(2), 126-130, 1967.

Grieshaber, M. K., Hardewig, I., Kreutzer, U., and Pörtner, H. O.: Physiological and metabolic responses to hypoxia in invertebrates, Rev. Physiol. Biochem. Pharmacol., 125, 43-147, 1994.

Grønkjær, P. and Wieland, K.: Ontogenetic and environmental effects on vertical distribution of cod larvae in the Bornholm Basin, Baltic Sea, Mar. Ecol.-Prog. Ser., 154, 91-105, 1997.

Grove, M. and Breitburg, D. L.: Growth and reproduction of gelatinous zooplankton exposed to low dissolved oxygen, Mar. Ecol.Prog. Ser., 301, 185-198, 2005.

Hagenmaier, H. E.: Zum Schlüpfprozess bei Fischen: II. Gewinnung und Charakterisierung des Schlüpfsekretes bei der Regenbogenforelle (Salmo gairdneri Rich.), Experientia (Basel), 28, 1214-1215, 1972.

Hampton, I. and Sweijd, N.: Achievements and lessons learned from the Benguela Environment, Fisheries, Interaction and Training (BENEFIT) research programme, Afr. J. Mar. Sci., 30, 541-564, doi:10.2989/AJMS.2008.30.3.9.643, 2008.

Hardewig, I., Addink, A. D. F., Grieshaber, M. K., Pörtner, H. O., and van den Thillart, G.: Metabolic rates at different oxygen levels determined by direct and indirect calorimetry in the oxyconformer Sipunculus nudus, J. Exp. Biol., 157, 143-160, 1991.

Hedges, K.: Effects of abiotic factors on predator-prey interactions in freshwater fish communities, Dissertation Univ. Manitoba, 1$210,2007$.
Helly, J. and Levin, L.: Global distribution of naturally occurring marine hypoxia on continental margins, Deep-Sea Res. Pt. I, 51, 1159-1168, 2004.

Herbert, N. A. and Steffensen, J. F.: The response of Atlantic cod, Gadus morhua, to progressive hypoxia: fish swimming speed and physiological stress, Mar. Biol., 147, 1403-1412, 2005.

Herring, P. J., Fasham, M. J. R., Weeks, A. R., Hemmings, J. C. P., Roe, H. S. J., Pugh, P. R., Holley, S., Crisp, N. A., and Angel, M. $\mathrm{V}$.: Across-slope relations between the biological populations, the euphotic zone and the oxygen minimum layer off the coast of Oman during the southwest monsoon (August, 1994), Prog. Oceanogr., 41, 69-109, 1998.

Herskin, J. and Steffensen, J. F.: Energy savings in sea bass swimming in a school: measurements of tail beat frequency and oxygen consumption at different swimming speeds, J. Fish. Biol., 53, 366-376, 1998.

Hoeger, U., Mommsen, T. P., Odor, R., and Webber, D.: Oxygenuptake and nitrogen-excreation in 2 cephalopods, Octopus and Squid, Comp. Biochem. Phys. A, 87, 63-67, 1987.

Holmes, J., Cooke, K., and Cronkite, G.: Interactions between Jumbo Squid (Dosidicus gigas) and Pacific Hake (Merluccius productus) in the northern California Current in 2007, CalCOFI Rep., 49, 129-141, 2008.

Houde, E. D. and Schekter, R.: Oxygen uptake and comparative energetics among eggs and larvae of three subtropical marine fishes, Mar. Biol., 72, 283-293, 1983.

Howell, P. and Simpson, D.: Abundance of marine resources in relation to dissolved oxygen in Long-Island Sound, Estuaries, 17, 394-402, 1994.

Hunt, J. C. and Seibel, B. A.: Life history of Gonatus onyx (Cephalopoda:Teuthoidea): ontogenetic changes in habitat, behavior and physiology, Mar. Biol., 136, 543-552, 2000.

IAPSO: The International system of units (SI) in oceanography, UNESCO Tech. Pap. Mar. Sci., 45, 1-131, 1985.

Invidia, M., Sei, S., and Gorbi, G.: Survival of the copepod Acartia tonsa following egg exposure to near anoxia and to sulfide at different pH values, Mar. Ecol.-Prog. Ser., 276, 187-196, 2004.

IOW: http://www.io-warnemuende.de/environmental-monitoring. html, last access: November 2009, 2009.

Jansson, B.-O.: The Baltic Sea, in: Large Marine Ecosystems of the World 12, edited by: Hempel, G. and Sherman, K., Elsevier, Amsterdam, 145-170, 2003.

Jennings, S. and Wilson, R. W.: Fishing impacts on the marine inorganic carbon cycle, J. Appl. Ecol., 46(5), 976-982, 2009.

Johansen, J., Herbert, N., and Steffensen, J. F.: The behavioural and physiological response of Atlantic cod Gadus morhua L. to short-term acute hypoxia, J. Fish. Biol., 68, 1918-1924, 2006.

Jordan, A. D. and Steffensen, J. F.: Effects of ration size and hypoxia on specific dynamic action in the cod, Physiol. Biochem. Zool., 80, 178-185, 2007.

Kaartvedt, S., Rostad, A., and Klevjer, T. A.: Sprat Sprattus sprattus can exploit low oxygen waters for overwintering, Mar. Ecol.Prog. Ser., 390, 237-249, 2009.

Karuppasamy, P. K., Menon, N. G., Nair, K. K. C., and Achuthankutty, C. T.: Distribution and abundance of pelagic shrimps from the deep scattering layer of the eastern Arabian Sea, J. Shellfish Res., 25, 1013-1019, 2006. 
Kassahn, K. S., Crozier, R. H., Pörtner, H. O., and Caley, M. J.: Animal performance and stress: responses and tolerance limits at different levels of biological organisation, Biol. Rev., 84, 277292, 2009.

Katajisto, T.: Effects of anoxia and hypoxia on the dormancy and survival of subitaneous eggs of Acartia bifilosa (Copepoda:Calanoida), Mar. Biol., 145(4), 751-757, 2004.

Keister, J. E., Houde, E. D., and Breitburg, D. L.: Effects of bottomlayer hypoxia on abundances and depth distributions of organisms in Patuxent River, Chesapeake Bay, Mar. Ecol.-Prog. Ser., 205, 43-59, 2000.

King, D.: Influence of temperature, dissolved oxygen and salinity on incubation and early larval development of the south west african pilchard, Sardinops ocellata, Sea Fisheries Branch Investigational Report, 114, 1977.

Kodama, K., Horiguchi, T., Kume, G., Nagayama, S., Shimizu, T., Shiraishi, H., Morita, M., and Shimizu, M.: Effects of hypoxia on early life history of the stomatopod Oratosquilla oratoria in a coastal sea, Mar. Ecol.-Prog. Ser., 324, 197-206, 2006.

Kostianoy, A. G. and Lutjeharms, J. R. E.: Atmospheric effects in the Angola-Benguela frontal zone, J. Geophys. Res, 104(C9), 20963-20970, 1999.

Kramer, D. L.: Dissolved-Oxygen and Fish Behavior, Environ. Biol. Fish., 18, 81-92, 1987.

Kreiner, A., Stenevik, E. K., and Ekau, W.: Sardine Sardinops sagax and anchovy Engraulis encrasicolus larvae avoid regions with low dissolved oxygen concentration in the northern Benguela Current system, J. Fish. Biol., 74, 270-277, doi:10.1111/jfb.2009.74.issue-1, 2009.

Kunzmann, A. and Buchholz, F.: Respiration physiology of fish larvae and krill from the Benguela system, Eastern boundary upwelling ecosystems, integrative and comparative approaches, 26 June 2008, Las Palmas, Gran Canaria, Spain, 189, 2008.

Lääne, A., Kraav, E., and Titova, G. D.: Baltic Sea, GIWA-regional assessment report, 17, 88 pp., 2005.

Landry, C. A., Steele, S. L., Manning, S., and Cheek, A. O.: Long term hypoxia suppresses reproductive capacity in the estuarine fish, Fundulus grandis, Comp. Biochem. Phys. A, 148, 317-323, 2007.

Levin, L. A., Ekau, W., Gooday, A. J., Jorissen, F., Middelburg, J. J., Naqvi, S. W. A., Neira, C., Rabalais, N. N., and Zhang, J.: Effects of natural and human-induced hypoxia on coastal benthos, Biogeosciences, 6, 2063-2098, doi:10.5194/bg-6-20632009, 2009.

Lluch-Cota, S. E., Aragon-Noriega, E. A., Arreguin-Sanchez, F., Aurioles-Gamboa, D., Bautista-Romero, J. J., Brusca, R. C., Cervantes-Duarte, R., Cortes-Altamirano, R., Del-MonteLuna, P., Esquivel-Herrera, A., Fernandez, G., Hendrickx, M. E., Hernandez-Vazquez, S., Herrera-Cervantes, H., Kahru, M., Lavin, M., Lluch-Belda, D., Lluch-Cota, D. B., Lopez-Martinez, J., Marinone, S. G., Nevarez-Martinez, M. O., Ortega-Garcia, S., Palacios-Castro, E., Pares-Sierra, A., Ponce-Diaz, G., RamirezRodriguez, M., Salinas-Zavala, C. A., Schwartzlose, R. A., and Sierra-Beltran, A. P.: The Gulf of California: Review of ecosystem status and sustainability challenges, Prog. Oceanogr., 73, 126, 2007.

Longhurst, A.: Vertical distribution of zooplankton in relation to eastern Pacific oxygen minimum, Deep-Sea Res., 14, 51-63, 1967.
Lozan, J., Lampe, R., Matthäus, W., Rachor, E., Rumohr, H., and Westernhagen, H. V.: Warnsignale aus der Ostsee, Paul Parey Verlag, Berlin, 385 p., 1996.

Lutjeharms, J. R. E. and Valentine, H.: Water types and volumetric considerations of the southeast Atlantic upwelling regime, Afr. J. Mar. Sci., 5, 63-71, 1987.

Lutz, R. V., Marcus, N. H., and Chanton, J.: Effects of low oxygen concentrations on the hatching and viability of eggs of marine calanoid copepods, Mar. Biol., 114, 241-247, 1992.

Lutz, R. V., Marcus, N. H., and Chanton, J.: Hatching and viability of copepod eggs at two stages of embryological development: anoxic/hypoxic effect, Mar. Biol., 119, 199-204, 1994.

Lynam, C. P., Gibbons, M. J., Axelsen, B. E., Sparks, C. A. J., Coetzee, J. C., Heywood, B. G., and Brierley, A. S.: Jellyfish overtake fish in a heavily fished ecosystem, Curr. Biol., 16, 492493, 2006.

Mac Gregor, J. M. and Houde, E. D.: Onshore-offshore pattern and variability in distribution and abundance of bay anchovy, Anchoa mitchilli, eggs and larvae in Chesapeake Bay, Mar. Ecol.-Prog. Ser., 138, 15-25, 1996.

Maes, J., Van Damme, P., Taillieu, A., and Ollevier, F.: Fish communities along an oxygen-poor salinity gradient (Zeeschelde Estuary, Belgium), J. Fish. Biol., 52, 534-546, 1998.

Mangum, C. and van Winkle, W.: Responses of aquatic invertebrates to declining oxygen conditions, Am. Zool., 13, 529-541, 1973.

Marcus, N. H. and Lutz, R. V.: Effects of anoxia on the viability of subitaneous eggs of planktonic copepods, Mar. Biol., 121, 8387, 1994.

Marcus, N. H., Lutz, R. V., and Chanton, J. P.: Impact of anoxia and sulfide on the viability of eggs of three planktonic copepods, Mar. Ecol.-Prog. Ser., 146, 291-295, 1997.

Marcus, N. H., Richmond, C., Sedlacek, C., Miller, G. A., and Oppert, C.: Impact of hypoxia on the survival, egg production and population dynamics of Acartia tonsa Dana, J. Exp. Mar. Biol. Ecol., 301, 111-128, 2004.

Massabuau, J. C.: From low arterial- to low tissue-oxygenation strategy - An evolutionary theory, Resp. Physiol., 128, 249-261, 2001.

Matsuura, Y. and Hewitt, R. P.: Changes in the spatial patchiness of Pacific mackerel, Scomber japonicus, larvae with increasing age and size, Fish. B-NOAA, 1(93), 172-178, 1995.

Matthäus, W.: Natural variability and human impacts reflected in longterm changes in the Baltic deep water conditions - A brief review, Ocean Dynam., 47, 47-65, 1995.

McQuoid, M. R., Godhe, A., and Nordberg, K.: Viability of phytoplankton resting stages in the sediments of a coastal Swedish fjord, Eur. J. Phycol., 37(2), 191-201, 2002.

Meehl, G. A., Stocker, T. F., Collins, W. D., Friedlingstein, P., Gaye, A. T., Gregory, J. M., Kitoh, A., Knutti, R., Murphy, J. M., Noda, A., Raper, S. C. B., Watterson, I. G., Weaver, A. J., and Zhao, Z.-C.: Global Climate Projections, in: Climate Change 2007: The Physical Science Basis, Contribution of Working Group I to the Fourth Assessment Report of the Intergovernmental Panel on Climate Change, edited by: Solomon, S., Qin, D., Manning, M., Chen, Z., Marquis, M., Averyt, K. B., Tignor, M., and Miller, H. L., Cambridge University Press, Cambridge, UK and New York, NY, USA, 2007. 
Mejía-Rebollo, A., Quinonez-Vel'azquez, C., Salinas Zavala, C. A., and Markaida, U.: Age, growth and maturity of jumbo squid (Dosidicus gigas D'Orbigny 1835) off the western coast of the Baja California Peninsula, CalCOFI Rep., 49, 256-262, 2008.

Messieh, S. N. and Rosenthal, H.: Mass mortality of herring eggs on spawning beds on and near Fisherman's Bank, Gulf of St. Lawrence, Canada, Aquat. Living Resour., 2, 1-8, 1989.

Miller, D., Poucher, S., and Coiro, L. L.: Determination of lethal dissolved oxygen levels for selected marine and estuarine fishes, crustaceans, and a bivalve, Mar. Biol., 140, 287-296, 2002.

Mincks, S. L., Bollens, S. M., Madin, L. P., Horgan, E., Butler, M., Kremer, P. M., and Craddock, J. E.: Distribution, abundance, and feeding ecology of decapods in the Arabian Sea, with implications for vertical flux, Deep-Sea Res. Pt. II, 47, 1475-1516, 2000.

Mohrholz, V., Schmidt, M., and Lutjeharms, J.: The hydrography and dynamics of the Angola-Benguela Frontal zone and environment in April 1999, Afr. J. Sci., 97, 199-208, 2001.

Mohrholz, V., Bartholomae, C. H., van der Plas, A., and Lass, H. U.: The seasonal variability of the northern Benguela undercurrent and its relation to the oxygen budget on the shelf, Cont. Shelf Res., 28, 424-441, doi:10.1016/j.csr.2007.10.001, 2008.

Monteiro, P. M. S., Vanderplas, A., Melice, J., and Florenchie, P.: Interannual hypoxia variability in a coastal upwelling system: Ocean-shelf exchange, climate and ecosystemstate implications, Deep-Sea Res. Pt. I, 55, 435-450, doi:10.1016/j.dsr.2007.12.010, 2008.

Morales-Bojorquez, E., Hernandez-Herrera, A., Nevarez-Martinez, M. O., Cisneros-Mata, M. A., and Guerrero-Escobedo, F. J.: Population size and exploitation of giant squid (Dosidicus gigas D'Orbigny, 1835) in the Gulf of California, Mexico, Scientia Marina, 65, 75-80, 2001.

Moss, S. A. and McFarland, W.: Influence of dissolved oxygen and carbon dioxide on fish schooling behavior, Mar. Biol., 5, 100107, 1970.

Munday, P. L., Crawley, N. E., and Nilsson, G. E.: Interacting effects of elevated temperature and ocean acidification on the aerobic performance of coral reef fishes, Mar. Ecol.-Prog. Ser., 388, 235-242, 2009.

Nelson, G. and Hutchings, L.: Passive Transportation of Pelagic System components in the Southern Benguela Area, S. Afr. J. Mar. Sci., 5, 223-234, 1987.

Neuenfeldt, S. and Beyer, J. E.: Oxygen and salinity characteristics of predator-prey distributional overlaps shown by predatory Baltic cod during spawning, J. Fish. Biol., 62(1), 168-183, 2003

Nilsson, G., Rosén, P., and Johansson, D.: Anoxic depression of spontaneous locomotor activity in crucian carp quantified by a computerized imaging technique, J. Exp. Biol., 180, 153-162, 1993.

Nilsson, G. E., Hobbs, J. A., Östlund-Nilsson, S., and Munday, P.: Hypoxia tolerance and airbreathing ability correlate with habitat preference in coral-dwelling fishes, Coral Reefs, 26, 241-248, 2007a.

Nilsson, G. E., Östlund-Nilsson, S., Penfold, R., and Grutter, A. S.: From record performance to hypoxia tolerance: respiratory transition in damselfish larvae settling on a coral reef, P. Roy. Soc B-Biol. Sci., 274, 79-85, 2007b.
Nilsson, G. E., Crawley, N., Lunde, I., and Munday, P. L.: Elevated temperature reduces the respiratory scope of coral reef fishes, Global Change Biol., 15, 1405-1412, 2009.

Nissling, A.: Survival of eggs and yolk-sac larvae of Baltic cod (Gadus morhua L.) at low oxygen levels in different salinities, ICES J. Mar. Sci., 198, 626-631, 1994.

Nissling, A. and Vallin, L.: The ability of Baltic cod eggs to maintain neutral buoyancy and the opportunity for survival in fluctuating conditions in the Baltic Sea, J. Fish. Biol., 48, 217-227, 1996.

O'Connor, T. and Whitall, D.: Linking hypoxia to shrimp catch in the northern Gulf of Mexico, Mar. Pollut. Bull., 54, 460-463, 2007.

Ojaveer, E. and Kalejs, M.: The impact of climate change on the adaptation of marine fish in the Baltic Sea, ICES J. Mar. Sci., 62(7), 1492-1500, 2005.

Oppen-Berntsen, D. O., Bogsnes, A., and Walther, B. T.: The Effects of hypoxia, alkalinity and neurochemicals on hatching of Atlantic salmon (Salmo salar) eggs, Aquaculture, 86, 417-430, 1990.

Oschlies, A., Schulz, K. G., Riebesell, U., and Schmittner, A.: Simulated 21st century's increase in oceanic suboxia by $\mathrm{CO}_{2-}$ enhanced biotic carbon export, Global Biogeochem. Cy., 22(4), 10 pp., 2008.

Palomera, I.: Vertical distribution of eggs and larvae of Engraulis encrasicolus in stratified waters of the western Mediterranean, Mar. Biol., 111, 37-44, 1991.

Parker-Stetter, S. and Horne, J.: Nekton distribution and midwater hypoxia: A seasonal, diel prey refuge? Estuar. Coast. Shelf S., 81, 13-18, 2009.

Paulmier, A. and Ruiz-Pino, D.: Oxygen minimum zones (OMZs) in the modern ocean, Prog. Oceanogr., 80(3-4), 113-128, 2009.

Pauly, D., Christensen, V., Dalsgaard, J., Froese, R., and Torres, F.: Fishing down marine food webs, Science, 279(5352), 860-863, 1998.

Pauly, D., Graham, W., Libralato, S., Morissette, L., and Palomares, M. L. D.: Jellyfish in ecosystems, online databases, and ecosystem models, Hydrobiologia, 616, 67-85, 2009.

Petersen, J. K. and Petersen, G. I.: Tolerance, behaviour and oxygen consumption in the sand goby, Pomatoschistus minutus (Pallas), exposed to hypoxia, J. Fish. Biol., 37, 921-933, 1990.

Pfeiler, E.: Changes in hypoxia tolerance during metamorphosis of bonefish leptocephali, J. Fish. Biol., 59, 1677-1681, doi:10.1006/jfbi.2001.1795, 2001.

Pichavant, K., Person Le Ruyet, J., Le Bayon, N., Severe, A., Le Roux, A., and Boeuf, G.: Comparative effects of long-term hypoxia on growth, feeding and oxygen consumption in juvenile turbot and European sea bass, J. Fish. Biol., 59, 875-883, doi:10.1006/jfbi.2001.1702, 2001.

Pierron, F., Baudrimont, M., Boudou, A., and Massabuau, J.: Effects of salinity and hypoxia on cadmium bioaccumulation in the shrimp Palaemon longirostris, Environ. Toxicol. Chem., 26, 1010-1017, 2007.

Pihl, L., Baden, S. P., and Diaz, R.: Effects of periodic hypoxia on distribution of demersal fish and crustaceans, Mar. Biol., 108, 349-360, 1991.

Pihl, L., Baden, S. P., Diaz, R., and Schaffner, L. C.: Hypoxiainduced structural changes in the diet of bottom-feeding fish and crustacea, Mar. Biol., 112, 349-361, 1992. 
Pihl, L.: Changes in the diet of demersal fish due to eutrophicationinduced hypoxia in the Kattegat, Sweden, Can. J. Fish. Aquat. Sci., 51(2), 321-336, 1994.

Pinz, I. and Pörtner, H. O.: Metabolic costs induced by lactate in the toad Bufo marinus: new mechanism behind oxygen debt?, J. Appl. Physiol., 94, 1177-1185, 2003.

Plante, S., Chabot, D., and Dutil, J. D.: Hypoxia tolerance in Atlantic cod, J. Fish. Biol., 53, 1342-1356, 1998.

Pörtner, H. O., Heisler, N., and Grieshaber, M. K.: Oxygen consumption and mode of energy production in the intertidal worm Sipunculus nudus L.: definition and characterization of the critical $p \mathrm{O}_{2}$ for an oxyconformer, Resp. Physiol., 59, 361-377, 1985.

Pörtner, H. O. and Grieshaber, M. K.: Critical $\mathrm{P}_{\mathrm{CO}_{2}}$ (s) in oxyconforming and oxyregulating animals: gas exchange, metabolic rate and the mode of energy production, in: The vertebrate gas transport cascade: adaptations to environment and mode of life, edited by: Bicudo, J. E. P. W., CRC Press Inc., Boca Raton FL, USA, 330-357, 1993.

Pörtner, H. O., Branco, L., Malvin, G., and Wood, S.: A new function for lactate in the toad Bufo marinus, J. Appl. Physiol., 76, 2405-2410, 1994.

Pörtner, H. O. and Zielinski, S.: Environmental constraints and the physiology of performance in squid, S. Afr. J. Mar. Sci., 20, 207221, 1998.

Pörtner, H. O., Reipschläger, A., and Heisler, N.: Metabolism and acid-base regulation in Sipunculus nudus as a function of ambient carbon dioxide, J. Exp. Biol., 201, 43-55, 1998.

Pörtner, H. O., Langenbuch, M., and Reipschlager, A.: Biological impact of elevated ocean $\mathrm{CO}_{2}$ concentrations: lessons from animal physiology and earth history, J. Oceanogr., 60, 705-718, 2004.

Pörtner, H. O. and Knust, R.: Climate change affects marine fishes through the oxygen limitation of thermal tolerance, Science, 315 , 95-97, doi:10.1126/science.1135471, 2007.

Pörtner, H. O. and Farrell, A. P.: Physiology and Climate Change, Science, 322, 690-692, 2008.

Pörtner, H. O., Bock, C., Knust, R., Lannig, G., Lucassen, M., Mark, F., and Sartoris, F.: Cod and climate in a latitudinal cline: physiological analyses of climate effects in marine fishes, Clim. Res., 37, 253-270, doi:10.3354/cr00766, 2008.

Pörtner, H. O. and Lannig, G.: Oxygen and capacity limited thermal tolerance, in: Fish Physiol., 27, Hypoxia, edited by: Richards, J. G., Farrell, A. P., and Brauner, C. J., Academic Press, 143-191, 2009.

Pörtner, H. O., Farrell, A. P., Knust, R., Lannig, G., Mark, F. C., and Storch, D.: Adapting to Climate Change Response, Science, 323, 876-877, 2009.

Pörtner, H. O.: Oxygen and capacity limitation of thermal tolerance: a matrix for integrating climate related stressors in marine ecosystems, J. Exp. Biol., 213, 881-893, 2010.

Powell, M. and Perry, S.: Respiratory and acid-base disturbances in rainbow trout blood during exposure to chloramine-T under hypoxia and hyperoxia, J. Fish. Biol., 50, 418-428, 1997.

Prince, E. D. and Goodyear, C. P.: Hypoxia-based habitat compression of tropical pelagic fishes, Fish. Oceanogr., 15, 451-464, 2006.
Purcell, J. E. and Sturdevant, M. V.: Prey selection and dietary overlap among zooplanktivorous jellyfish and juvenile fishes in Prince William Sound, Alaska, Mar. Ecol.-Prog. Ser., 210, 6783, 2001.

Purcell, J. E. and Decker, M. B.: Effects of climate on relative predation by scyphomedusae and ctenophores on copepods in Chesapeake during 1987-2000, Limnol. Oceanogr., 50(1), 376387, 2005.

Purcell, J. E., Uye, S., and Lo, W.: Anthropogenic causes of jellyfish blooms and their direct consequences for humans: a review, Mar. Ecol.-Prog. Ser., 350, 153-174, 2007.

Rabalais, N. N. and Eugene Turner, R.: Responses of nekton and demersal and benthic fauna to decreasing oxygen concentrations, in: Coastal Hypoxia: Consequences for Living Resources and Ecosystems, edited by: Rabalais, N. N. and Turner, R. E., 115128, 2001.

Renaud, M. L.: Detecting and avoiding oxygen deficient sea water by brown shrimp, Penaeus aztecus (Ives), and white shrimp Penaeus setiferus (Linnaeus), J. Exp. Mar. Biol. Ecol., 98, 283-292, 1986.

Rheinheimer, G.: Meereskunde der Ostsee, Springer Verlag, BerlinHeidelberg, 2nd edition, 338 pp., 1995.

Richardson, A. J., Bakun, A., Hays, G. C., and Gibbons, M. J.: The jellyfish joyride: causes, consequences and management responses to a more gelatinous future, Trends Ecol. Evol., 24(6), 312-322, 2009.

Roberts, M. J. and Sauer, W. H. H.: Environment: the key to understanding the South African chokka squid (Loligo vulgaris reynaudii) life cycle and fishery? Antarct. Sci., 6, 249-258, 1994.

Roberts, M. J.: Chokka squid (Loligo vulgaris reynaudii) abundance linked to changes in South Africa's Agulhas Bank ecosystem during spawning and the early life cycle, Ices J. Mar. Sci., 62, 33-55, doi:10.1016/j.icesjms.2004.10.002, 2005.

Röckmann, C., Schneider, U. A., St. John, M. A., and Tol, R. S. J.: Rebuilding the eastern Baltic cod stock under environmental change - A preliminary approach using stock, environmental, and management constraints, Nat. Resour. Model, 20(2), 223262, 2007.

Röckmann, C., Tol, R. S. J., Schneider, U. A. and St. John, M. A.: Rebuilding the eastern Baltic cod stock under environmental change (Part II): Taking into account the costs of a marine protected area, Nat. Resour. Model, 22(1), 1-25, 2009.

Rodhouse, P. G.: Large-scale range expansion and variability in ommastrephid squid populations: A review of environtmental links, CalCOFI Rep., 49, 83-90, 2008.

Roman, M. R., Gauzens, A. L., Rhinehart, W. K. and White, J. R.: Effects of low oxygen waters on Chesapeake Bay zooplankton, Limnol. Oceanogr., 38(8), 1603-1614, 1993.

Rosa, R. and Seibel, B. A.: Synergistic effects of climaterelated variables suggest future physiological impairment in a top oceanic predator, P. Natl. Acad. Sci., 105(52), 20776-20780, 2008.

Rosenberger, A. and Chapman, L. J.: Hypoxic wetland tributaries as faunal refugia from an introduced predator, Ecol. Freshwater Fish, 8, 22-34, 1999.

Rumohr, H.: Zoobenthos, in: Meereskunde der Ostsee, edited by: Rheinheimer, G., Springer Verlag, Berlin-Heidelberg, 2nd edition, 173-180, 1995. 
Rutherford Jr., L. D. and Thuesen, E. V.: Metabolic performance and survival of medusae in estuarine hypoxia, Mar. Ecol.-Prog. Ser., 294, 189-200, 2005.

Saint-Paul, U., Hubold, G. and Ekau, W.: Acclimation effects on routine oxygen-consumption of the Antarctic fish Pogonophryne scotti (Artedidraconidae), Pol. Biol., 9, 125-128, 1988.

Saltzman, J. and Wishner, K.: Zooplankton ecology in the eastern tropical Pacific oxygen minimum zone above a seamount: 1. General trends, Deep-Sea Res. Pt. I, 44(6), 907-930, 1997a.

Saltzman, J. and Wishner, K.: Zooplankton ecology in the eastern tropical Pacific oxygen minimum zone above a seamount: 2. Vertical distribution of copepods, Deep-Sea Res. Pt. I, 44(6), 931-954, 1997b.

Sameoto, D.: Influence of the biological and physical environment on the vertical distribution of mesozooplankton and micronekton in the eastern tropical Pacific, Mar. Biol., 93, 263-279, 1986.

Sameoto, D., Guglielmo, L., and Lewis, M. K.: Day/night vertical distribution of euphausiids in the eastern tropical Pacific, Mar. Biol., 96(2), 235-245, 1987.

Saroglia, M., Terova, G., De Stradis, A., and Caputo, A.: Morphometric adaptations of sea bass gills to different dissolved oxygen partial pressures, J. Fish. Biol., 60, 1423-1430, doi:10.1006/jfbi.2002.1945, 2002.

Schaefer, K. M., Fuller, D. W., and Block, B. A.: Movements, behavior, and habitat utilization of yellowfin tuna (Thunnus albacares) in the northeastern Pacific Ocean, ascertained through archival tag data, Mar. Biol., 152(3), 503-525, 2007.

Schnack, D.: Reproduktionsbiologie der Fische, in: Meereskunde der Ostsee, edited by: Rheinheimer, G., Springer Verlag, BerlinHeidelberg, 2nd edition, 265-272, 1995.

Schnack, D.: Ursachen großer Bestandsveränderungen in der Ostsee, Meer und Museum, 17, 96-103, 2003.

Schurmann, H. and Steffensen, J. F.: Effects of temperature, hypoxia and activity on the metabolism of juvenile Atlantic cod, J. Fish. Biol., 50, 1166-1180, 1997.

Seibel, B. A., Thuesen, E. V., Childress, J. J., and Gorodezky, L. A.: Decline in pelagic cephalopod metabolism with habitat depth reflects differences in locomotory efficiency, Biol. Bull., 192, 262278, 1997.

Sepulveda, C., Dickson, K. A., and Graham, J.: Swimming performance studies on the eastern Pacific bonito Sarda chiliensis, a close relative of the of the tunas (family Scombridae) I. Energetics, J. Exp. Biol., 206, 2739-2748, 2003.

Shang, E. H. H. and Wu, R. S.: Aquatic hypoxia is a teratogen and affects fish embryonic development, Environ. Sci. Technol., 38, 4763-4767, 2004.

Shannon, L. V.: The Benguela ecosystem. 1. Evolution of the Benguela, physical features and processes, in: Oceanography and Marine Biology, An Annual Review, 23, edited by: Barnes, M., Aberdeen, University Press, 105-182, 1985.

Shoji, J., Masuda, R., Yamashita, Y., and Tanaka, M.: Effect of low dissolved oxygen concentrations on behavior and predation rates on red sea bream Pagrus major larvae by the jellyfish Aurelia aurita and by juvenile Spanish mackerel Scomberomorus niphonius, Mar. Biol., 147, 863-868, 2005a.

Shoji, J., Masuda, R., Yamashita, Y., and Tanaka, M.: Predation on fish larvae by moon jellyfish Aurelia aurita under low dissolved oxygen concentrations, Fisheries Sci., 71, 748-753, 2005b.
Snelgrove, P. V. R., Flitner, M., Urban Jr., E. R., Ekau, W., Glaser, M., Lotze, H. K., Philippart, C. J. M., Sompnogchaiyakul, P., Yuwono, E., Melillo, J. M., Meybeck, M., Rabalais, N. N., and Zhang, J.: Governance and Management of Ecosystem Services in Semi-enclosed marine systems, in: Watersheds, Bays and Bounded Seas, edited by: Urban Jr., E. R., Sundby, B., Malanotte-Rizzoli, P., and Melillo, J. M., Island Press, Washington, 49-76, 2009.

Spoor, W.: Oxygen requirements of larvae of the smallmouth bass, Micropterus dolomieui Lacepede, J. Fish. Biol., 25, 587-592, 1984.

Steffensen, J. F.: Possible limitations of speed and size of swimming fish schools, based on oxygen-consumption of herring, Clupea harengus, measured at different swimming speeds, J. Physiol.London, 483P, P192-P192, 1995.

Stevens, P. W., Blewett, D. A., and Casey, J. P.: Short-term effects of a low dissolved oxygen event on estuarine fish assemblages following the passage of hurricane Charley, Estuar. Coast., 29, 997-1003, 2006.

Stramma, L., Johnson, G., Sprintall, J., and Mohrholz, V.: Expanding Oxygen-Minimum Zones in the tropical oceans, Science, 320, 655-658, doi:10.1126/science.1153847, 2008.

Svetlichny, L. S. and Hubareva, E. S.: Effect of oxygen concentration on metabolism and locomotory activity of Moina micrura (Cladocera) cultured under hypo- and normoxia, Mar. Biol., 141(1), 145-151, 2002.

Tang, M. and Boisclair, D.: Relationship between respiration rate of juvenile brook trout (Salvelinus fontinalis), water temperature, and swimming characteristics, Can. J. Fish. Aquat. Sci., 52, 2138-2145, 1995.

Tanner, C. A., Burnett, L. E., and Burnett, K. G.: The effects of hypoxia and $\mathrm{pH}$ on phenoloxidase activity in the Atlantic blue crab, Callinectes sapidus, Comp. Biochem. Phys. A, 144, $218-$ 223, 2006.

Taylor, J. C. and Rand, P. S.: Spatial overlap and distribution of anchovies (Anchoa spp.) and copepods in a shallow stratified estuary, Aquat. Living Resour., 16, 191-196, 2003.

Taylor, J. C., Rand, P. S., and Jenkins, J.: Swimming behavior of juvenile anchovies (Anchoa spp.) in an episodically hypoxic estuary: implications for individual energetics and trophic dynamics, Mar. Biol., 152, 939-957, 2007.

Thomas, P., Rahman, M. S., Kummer, J. A., and Lawson, S.: Reproductive endocrine dysfunction in Atlantic croaker exposed to hypoxia, Mar. Environ. Res., 62, S249-S252, 2006.

Thuesen, E. V. and Childress, J. J.: Oxygen consumption rates and metabolic enzyme activities of oceanic California medusae in relation to body size and depth, Biol. Bull., 187, 84-98, 1994.

Tschischka, K., Abele, D., and Pörtner, H. O.: Mitochondrial oxyconformity and cold adaptation in the polychaete Nereis pelagica and the bivalve Arctica islandica from the Baltic and White Seas, J. Exp. Biol., 203, 3355-3368, 2000.

Tyler, R. M. and Targett, T. E.: Juvenile weakfish Cynoscion regalis distribution in relation to diel-cycling dissolved oxygen in an estuarine tributary, Mar. Ecol.-Prog. Ser., 333, 257-269, 2007.

van der Lingen, C. D.: Respiration rate of adult pilchard Sardinops sagax in relation to temperature, voluntary swimming speed and feeding behaviour, Mar. Ecol.-Prog. Ser., 129, 41-54, 1995. 
Vaquer-Sunyer, R. and Duarte, C. M.: Thresholds of hypoxia for marine biodiversity, P. Natl. Acad. Sci. USA, 105(40), 1545215457, 2008.

Verheye, H. M., Hagen, W., Auel, H., Ekau, W., Loick, N., Rheenen, I., Wencke, P. and Jones, S.: Life strategies, energetics and growth characteristics of Calanoides carinatus (Copepoda) in the Angola-Benguela frontal region, Afr. J. Mar. Sci., 27, 641-651, 2005.

Vetter, R., Kohin, S., Preti, A., McClatchie, S., and Dewar, H.: Predatory interactions and niche overlap between mako shark, Isurus oxyrinchus, and jumbo squid, Dosidicus gigas, in the California Current, CalCOFI Rep., 49, 142-156, 2008.

Wang, S., Yuen, S. S. F., Randall, D. J., Hung, C. Y., Tsui, T. K. N., Poon, W. L., Lai, J. C. C, Zhang, Y., and Lin, H.: Hypoxia inhibits fish spawning via $\mathrm{LH}$-dependent final oocyte maturation, Comp. Biochem. Phys. C, 148(4), 363-369, 2008.

Wannamaker, C. and Rice, J.: Effects of hypoxia on movements and behavior of selected estuarine organisms from the southeastern United States, J. Exp. Mar. Biol. Ecol., 249, 145-163, 2000.

Weltzien, F. A., Doving, K. B., and Carr, W. E. S.: Avoidance reaction of yolk-sac larvae of the inland silverside Menidia beryllina (Atherinidae) to hypoxia, J. Exp. Biol., 202, 2869-2876, 1999.

Westernhagen, H. V. and Dethlefsen, V.: North Sea oxygen deficiency 1982 and its effects on the bottom fauna, Ambio, 12, 264266, 1983.

Widmer, S., Moore, F. B., and Bagatto, B.: The effects of chronic developmental hypoxia on swimming performance in zebrafish, J. Fish. Biol., 69, 1885-1891, 2006.
Wieland, K.: Einfluss der Hydrographie auf die Vertikalverteilung und Sterblichkeit der Eier des Ostseedorsches (Gadus morhua) im Bornholm-Becken, südliche zentrale Ostsee, Ber. Inst. Meeresk. Kiel, 266 pp., 1995.

Wishner, K. F., Ashjian, C. J., Gelfman, C., Gowing, M. M., Kann, L., Levin, L. A., Mullineaux, L. S., and Saltzman, J.: Pelagic and benthic ecology of the lower interface of the eastern tropical Pacific Oxygen Minimum Zone, Deep-Sea Res. Pt. I, 42(1), 93 115, 1995.

Wishner, K. F., Gelfman, C., Gowing, M. M., Outram, D. M., Rapien, M., and Williams, R. L.: Vertical zonation and distributions of calanoid copepods through the lower oxycline of the Arabian Sea oxygen minimum zone, Prog. Oceanogr., 78, 163191, 2008.

Zakhartsev, M. V., De Wachter, B., Sartoris, F., Pörtner, H. O., and Blust, R.: Thermal physiology of the common eelpout (Zoarces viviparus), J. Comp. Physiol. B, 173, 365-378, 2003.

Zettler, M. L., Borchert, R., and Pollehne, F.: Macrozoobenthos diversity in an oxygen minimum zone off northern Namibia, Mar. Biol., 156(9), 1949-1961, 2009.

Zielinski, S., Lee, P. G., and Pörtner, H. O.: Metabolic performance of the squid Lolliguncula brevis (Cephalopoda) during hypoxia: an analysis of the critical $\mathrm{P}_{\mathrm{O}_{2}}$, J. Exp. Mar. Biol. Ecol., 243, 241259, 2000.

Zimmerman, R. J. and Nance, L. M.: Effects of hypoxia on the shrimp fishery of Louisiana and Texas, in: Coastal hypoxia: Consequences for living resources and ecosystems, edited by: Rabalais, N. N. and Turner R. E., American Geographical Union, Washington, DC, 293-310, 2001. 